\title{
20. NEOGENE AND QUATERNARY PALEOENVIRONMENTAL HISTORY OF DEEP SEA DRILLING PROJECT LEG 71 SEDIMENTS, SOUTHWEST ATLANTIC OCEAN1
}

\author{
Paul F. Ciesielski, Department of Geology, University of Georgia, Athens, Georgia \\ and \\ Fred M. Weaver, Exxon Production Research Company, Houston, Texas
}

\begin{abstract}
The Neogene and Quaternary sedimentary record of Leg 71 and previously drilled sequences from the Southern Ocean reveal evidence of a major late Miocene change of oceanic and glacial conditions in the southern high latitudes during paleomagnetic Chron 9. The characteristics of late Miocene sedimentation and in particular the study of erosional patterns and ice-rafted debris suggest the following conclusions.

1) In the late Miocene, the Polar Front first migrated to the northern latitudes of the Southern Ocean and surface water temperatures became similar to those of today.

2) Extensive ice shelves or ice tongues were not present along the Antarctic margin until late Chron $9(\sim 9.0 \mathrm{Ma})$.

3) Before Chron 9, West Antarctica was occupied by an archipelago and the West Antarctic Sea.

4) Extensive ice shelves formed in the West Antarctic region, eventually coalescing and thickening to form the grounded West Antarctic ice sheet by Chron 9.

5) The newly formed West Antarctic ice sheet was probably unstable and frequently became an ungrounded ice shelf, thus accounting for the scarcity of late Miocene ice-rafted debris.

6) Extensive erosion or nondeposition of sediment was probably the result of increased Antarctic Bottom Water (AABW) formation in the West Antarctic region during the initial formation of extensive West Antarctic ice shelves and during periods when the West Antarctic ice sheet was ungrounded.

7) In the Southwest Atlantic, AABW velocity waned during the latest Miocene. During the late Gilbert Chron a major and permanent change occurred in the pattern of ice-rafting to the South Atlantic, and after 4.35 Ma the increased IRD accumulation rate and frequency of major episodes of IRD accumulation suggest increased stability of the West Antarctic ice sheet.

In addition, radiolarian faunas of Hole 514 record at least eight migrations of the Polar Front to the north of the site during the past 4.07 m.y. An apparent increase in the frequency of Polar Front migrations occurred $\sim 2.7-2.6 \mathrm{Ma}$, possibly in response to oceanic change induced by fluctuations in glacial conditions of the Northern Hemisphere.
\end{abstract}

\section{INTRODUCTION}

Deep Sea Drilling Project Leg 71 was the fifth cruise of the Glomar Challenger to drill in the southern high latitudes. Legs 28 and 29 drilled in the Southwest Pacific, Leg 35 in the Southeast Pacific, and Leg 36 in the Southwest Atlantic Ocean, on or in the vicinity of the Falkland Plateau. Leg 71 rotary drilled or hydraulic piston cored four subantarctic sites (Fig. 1), two on the Falkland Plateau (Site 511 in the basin province of the Plateau and Site 512 on the northeastern part of the Maurice Ewing Bank) and two (Sites 513 and 514) on the lower west flank of the Mid-Atlantic Ridge. Sites 511 and 512 lie within the present-day Antarctic Convergence zone (Gordon et al., 1977; Ciesielski, 1978), Sites 513 and 514 north of it.

Neogene and Quaternary sediments were recovered from all four sites (Fig. 2). Sites 511 and 512 recovered short Pliocene-Quaternary sections. Site 512 also contains a short upper middle to lower upper Miocene sedimentary sequence. The most complete Neogene and Quaternary sequences were recovered at Sites 513 and 514. Site 513 contains upper Miocene sediment repre-

\footnotetext{
${ }^{1}$ Ludwig, W. J., Krasheninnikov, v. A., et al., Init. Repts. DSDP, 71: Washington (U.S. Govt. Printing Office).
}

senting paleomagnetic Chrons 9, 6, and 5; Chrons 7 and 8 are absent. Sites 513 and 514 both contain lengthy Pliocene-Pleistocene sedimentary sequences punctuated by a single major hiatus spanning the latest Gilbert to the mid Gauss chrons. The base of Site 514 occurs immediately above the Thvera Subchron of the Gilbert Chron; however, Site 513 provides a nearly complete record of the portion of the Pliocene that precedes the Thvera Subchron. Thus Sites 513 and 514 contain a composite record of the entire Plio-Pleistocene except for the presence of an uppermost Gilbert to mid Gauss Chronozone disconformity.

This synthesis of the Neogene-Quaternary paleoenvironment of Leg 71 sites will concentrate on evidence from Sites 513 and 514 because of the more complete sedimentary record and high sediment accumulation rates of these sites. We focus our discussion of Neogene-Quaternary paleoenvironment on three aspects of the Leg 71 sedimentary record: the occurrence of disconformities, the distribution and abundance of icerafted detritus (IRD), and changes in the siliceous faunal assemblages as indicators of water mass fluctuations and Polar Front zonal migration through time. In addition, we attempt to relate the late Miocene-Pleistocene paleoenvironmental records of the Leg 71 sites to other regions of the Southern Ocean and major aspects of Neogene-Quaternary global paleoceanic evolution. 


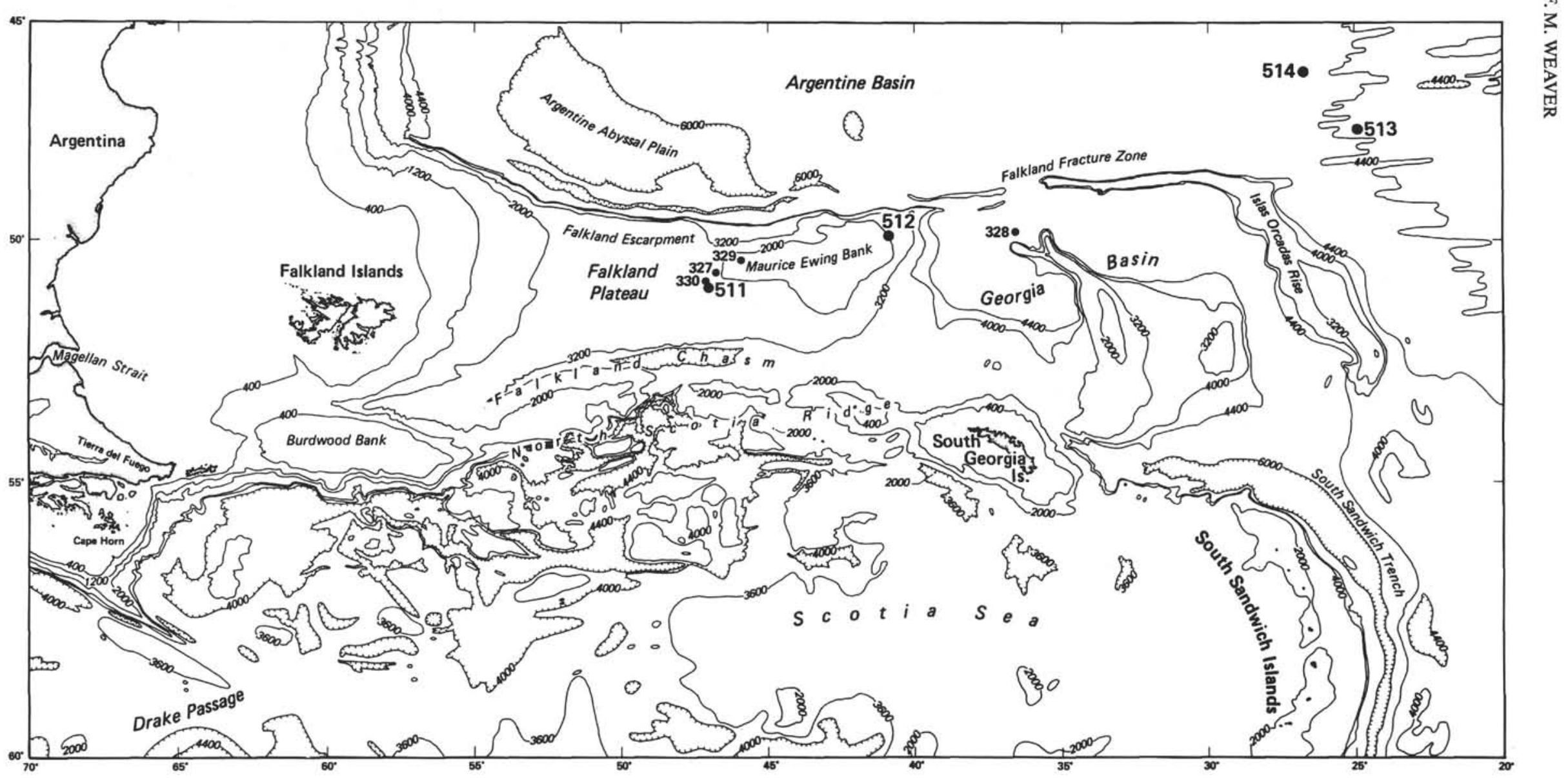

Figure 1. Location of DSDP Leg 71 sites. 

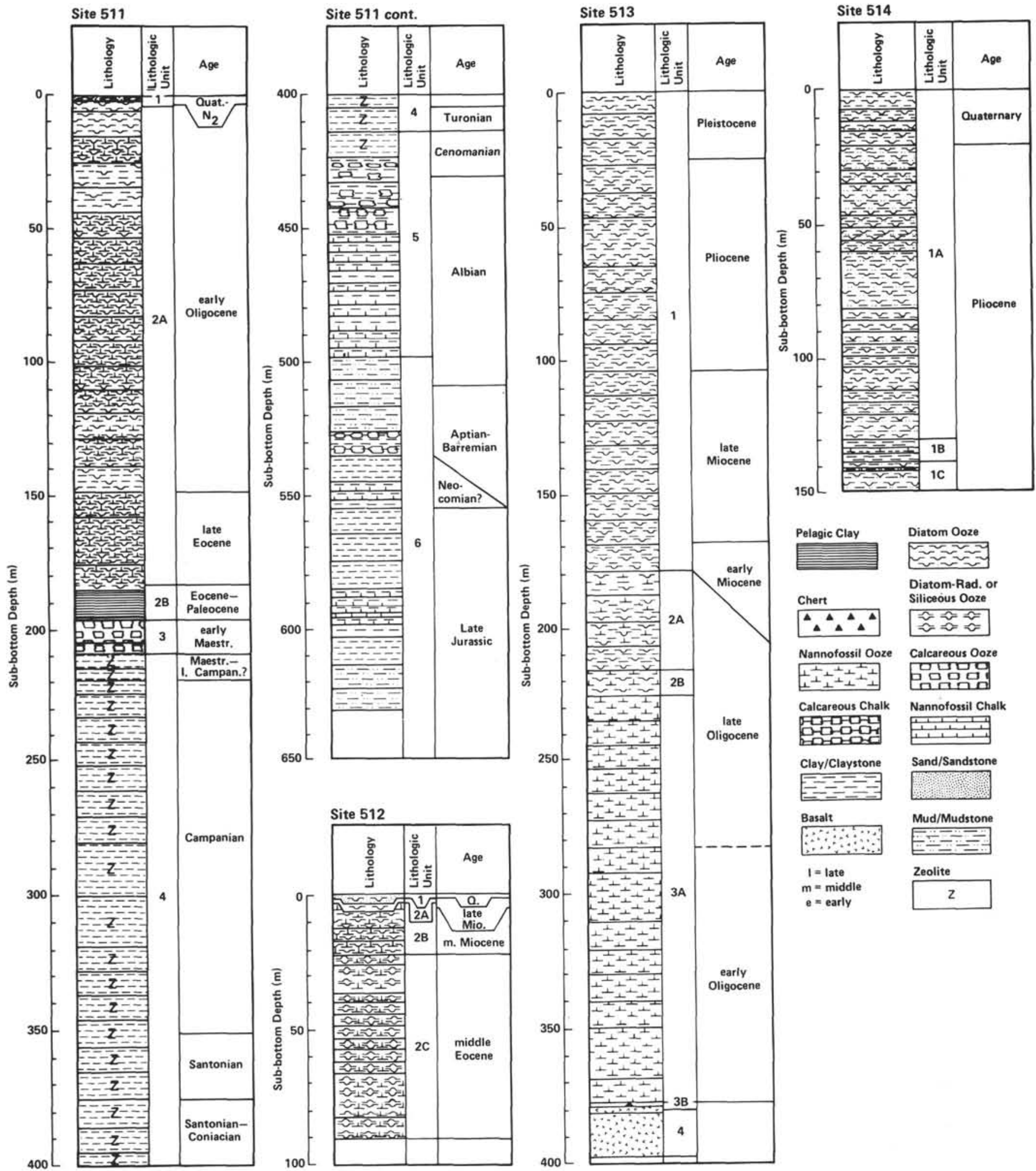

Figure 2. Lithologic columnar sections of DSDP Leg 71 sites.

\section{AGE DETERMINATIONS}

The chronology of paleoenvironmental events presented herein is based on the micropaleontologic studies of Ciesielski and Weaver (both this volume), the magnetostratigraphy of Ledbetter, Salloway, and Bloemendal

(all this volume), and a ${ }^{40} \mathrm{Ar} /{ }^{39} \mathrm{Ar}$ age determination of a volcanic ash layer. The age of Site 511 Neogene-Quaternary sediments is based primarily on the diatom stratigraphy of Ciesielski (this volume, Table 1) which has been correlated to magnetostratigraphy (Fig. 3). Sediment ages of Pliocene-Pleistocene sediments of Site 512 


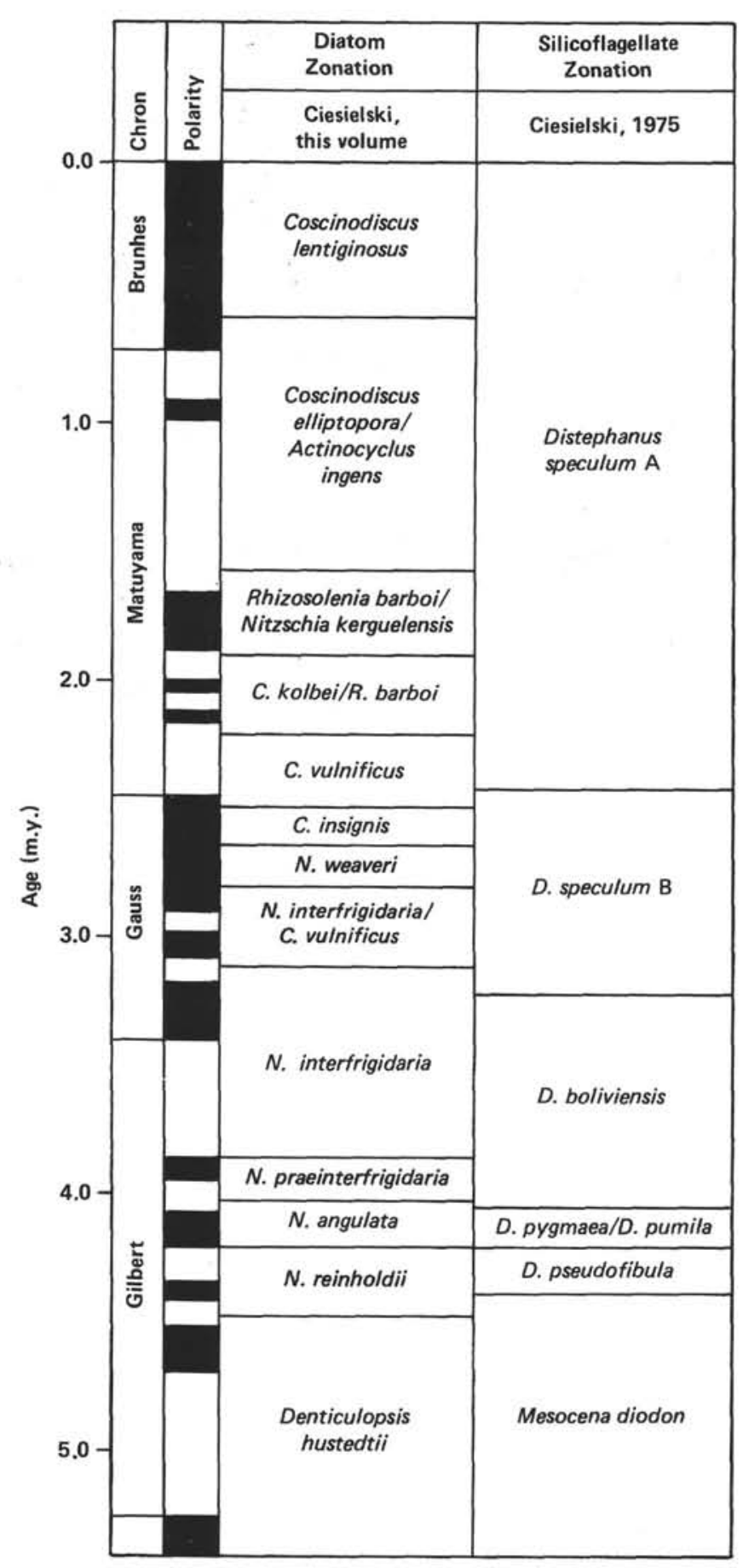

Figure 3. Pliocene to Quaternary diatom and silicoflagellate zonation, correlated to paleomagnetic stratigraphy.

are also based primarily on the diatom stratigraphy of Ciesielski (this volume, Table 2). The hydraulic piston cored Miocene sediments of Site 512 were dated by correlation of the magnetostratigraphic record (Ledbetter, this volume) to the standard magnetostratigraphic time scale (Site 512 chapter, Weaver, both this volume; Ciesielski, this volume, Table 2, Fig. 7). The Pliocene-Pleistocene stratigraphy of Sites 513 and 514 is based on the radiolarian stratigraphy of Weaver (this volume) and the diatom stratigraphy of Ciesielski (this volume). The magnetostratigraphic record of hydraulically piston cored Site 514 (Salloway, Bloemendal, both this volume) provides absolute age control for this site. The ages of Miocene sediments from Site 513 are based on our correlation of diatom, radiolarian, and silicoflagellate biostratigraphic zones to magnetostratigraphy (Fig. 4). A number of intrazonal datums also provide additional correlation of the Miocene section of Site 513 (Ciesielski, Weaver, both this volume). Some Miocene datums have been correlated to the magnetostratigraphic record of middle-latitude piston cores, whereas others we correlated to the magnetostratigraphic record of Southern Ocean cores (e.g., Islas Orcadas 7-2, 7-48, 7-54, 16$108,16-107$, and others). In addition, a ${ }^{40} \mathrm{Ar} /{ }^{39} \mathrm{Ar}$ age date (by R. D. Dallmeyer of the University of Georgia, pers. comm., 1981) for a volcanic ash near the base of the Site 513 Miocene section (Core 513A-10) provides an important absolute age for the basal portion of the Neogene section of this site.

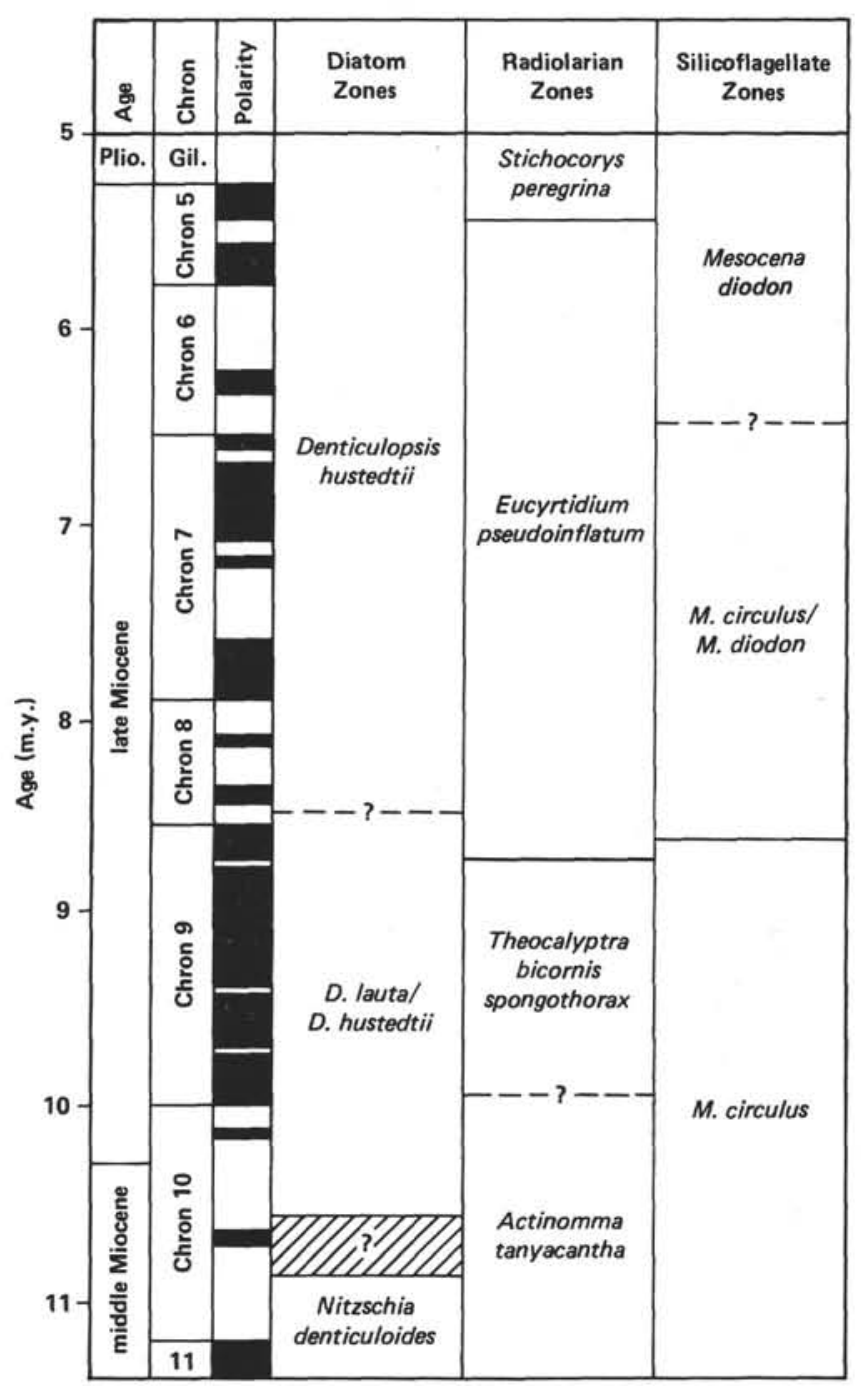

Figure 4. Upper middle Miocene to upper Miocene diatom, radiolarian, and silicoflagellate zones correlated to paleomagnetic stratigraphy. 


\section{PLIOCENE-PLEISTOCENE PALEOENVIRONMENTS}

\section{Unconformities}

Detailed paleontological analyses of Pliocene and Quaternary sediments from Holes 511 and 512 on the Maurice Ewing Bank and 513, 513A, and 514 on the southwestern flank of the Mid-Atlantic Ridge reveal the existence of three unconformities (Ciesielski, Weaver; both this volume). Figure 5 illustrates the age and duration of the unconformities relative to the paleomagnetic and geochronometric time scales.

The most widespread hiatus is observed in Holes 512, $513,513 \mathrm{~A}$, and 514 . It is mid-Pliocene in age and spans the interval from about 3.9 to $3.0 \mathrm{Ma}$; most upper Gilbert to mid-Gauss sediments are missing (Fig. 5). This hiatus is prominent throughout the southwestern Atlantic (Ciesielski et al., 1982). It occurred during a time of

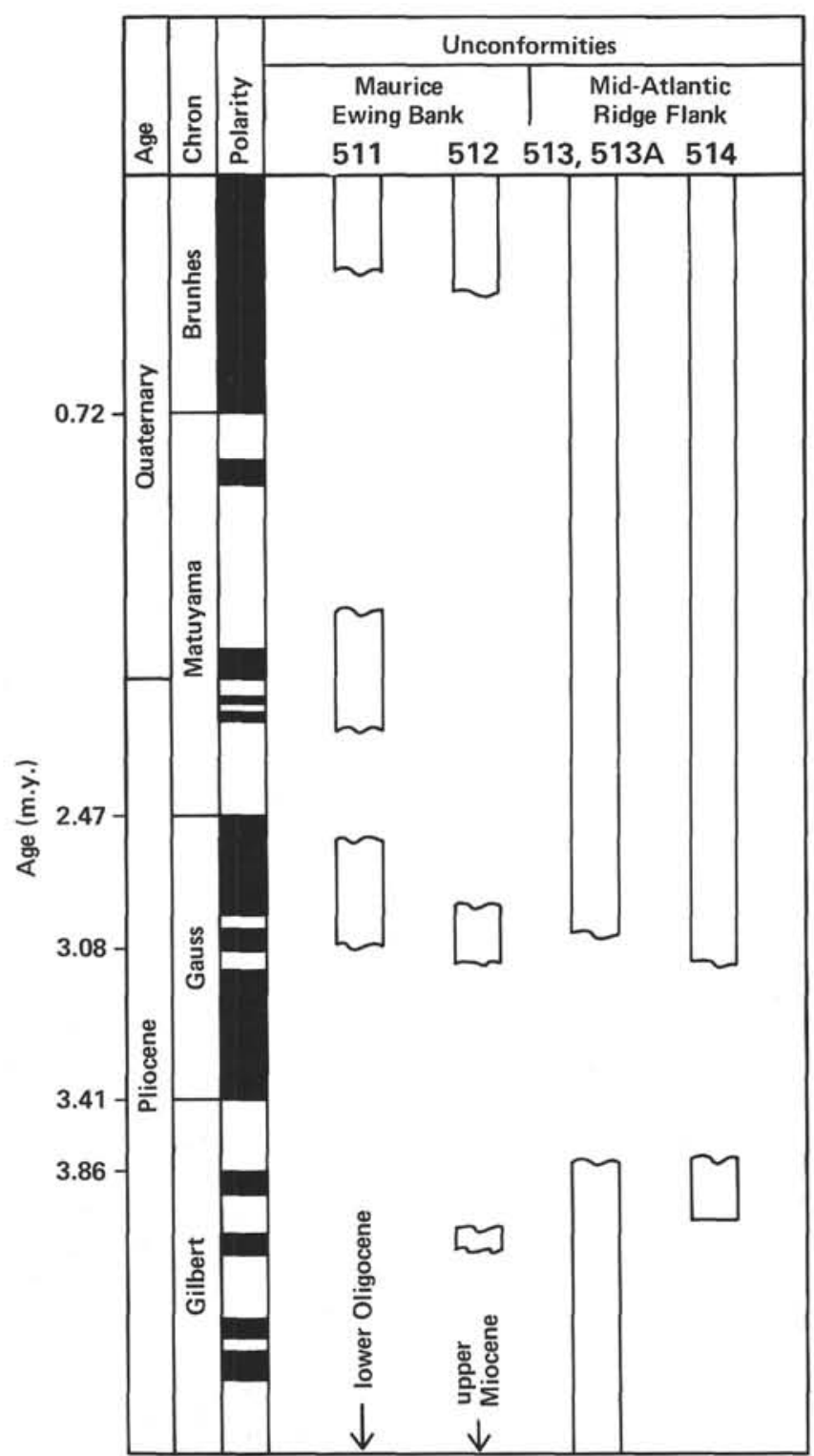

Figure 5. Pliocene-Quaternary unconformities in DSDP Leg 71 holes. intense glacial conditions in Argentinian Patagonia and of increased sea-ice conditions around Antarctica (Mercer, 1976; Weaver, 1973). Ciesielski et al. (1982) believe that this hiatus is erosional and that it was produced by a climatically induced intensification of the Antarctic Circumpolar Current (ACC).

The penultimate unconformity occurs in Hole 511 on the Maurice Ewing Bank (Fig. 5) and spans the Gauss/ Matuyama boundary. This hiatus is also likely to be a result of erosion as the ACC intensified in response to cooler climatic conditions throughout the region. Although this hiatus is not observed in other Leg 71 holes, it has been documented in other areas of the Southern Ocean (Weaver and McCollum, 1974).

The final unconformity that we recognize is in Hole 511 and encompasses the upper Matuyama and lower Brunhes paleomagnetic chronozones. This hiatus has been well defined throughout the area by Ciesielski et al. (1982), who conclude that it was produced by erosion and nondeposition resulting from a more intense ACC over the Bank, again in response to climatic cooling. This hiatus is correlated in time with the greatest Patagonian glaciation (Mercer, 1976; Ciesielski et al., 1982).

\section{Polar Front History}

One of the primary objectives of Leg 71 was to collect two coeval stratigraphic sections along a transect from the present Polar Front Zone to its most northerly inferred position during the late Cenozoic. These holes would allow us to reconstruct the paleoceanography of the region by documenting (1) the evolution and magnitude of shifts in the Polar Front Zone through time, (2) changes in the paleogeographic distribution of all microfossil groups, and (3) fluctuations in the rates of biogenic productivity along the Polar Front transect.

Two holes, $513\left(47^{\circ} 34.99^{\prime} \mathrm{S}, 24^{\circ} 38.40^{\prime} \mathrm{W} ; 4373 \mathrm{~m}\right)$, on the western edge of the Mid-Atlantic Ridge, and 514 $\left(46^{\circ} 02.77^{\prime} \mathrm{S}, 26^{\circ} 51.30^{\prime} \mathrm{W} ; 4318 \mathrm{~m}\right)$, on the lower west flank of the Ridge, were drilled for use as a Polar Front transect. Hole 514 is approximately $400 \mathrm{~km}$ and Hole $513240 \mathrm{~km}$ north of the present mean position of the Polar Front Zone. Our original Hole 513, located at the present Polar Front, was eventually abandoned because of severe iceberg conditions.

Preliminary paleontological examination of the radiolarian fauna at Hole 513 indicated that the Pliocene and Quaternary section did not show any evidence of significant shifts in the Polar Front except for one sample in Core 6. Further, most Hole 514 samples studied indicated a position at or relatively near the Polar Front for the Late Pliocene to Quaternary. The greater faunal variability and paleomagnetic record of Hole 514 caused us to concentrate on this hole for documenting Polar Front migrations during the late Cenozoic.

At Hole 514, 35 HPC cores were attempted for a $92 \%$ recovery rate. The oldest sediment collected is approximately $4.07 \mathrm{~m} . \mathrm{y}$. old and except for one hiatus between Cores 26 and 27, spanning 674,000 y., the remaining Pliocene and Quaternary section appears to be complete, although sedimentation rates are much less in the Quaternary. (The Pliocene and Quaternary siliceous mi- 
crofossil and paleomagnetic stratigraphy of Hole 514 can be found in other chapters of this volume.)

To document Polar Front migrations we have used only radiolarian data because we understand their Recent biogeography relative to the Polar Front better than we do that of other siliceous microfossil groups. Biogeographic data on radiolarians in plankton and in bottom samples from subantarctic and antarctic regions are well documented in Hays (1965), Petrushevskaya (1968), Nigrini (1967), Lozano and Hays (1976), Nigrini and Moore (1979), and Payne (1977).

Hays (1965), using surface samples, documented the distribution of a distinct cold-water antarctic radiolarian fauna primarily south of the Polar Front and a warm-water radiolarian assemblage north of the Polar Front. He recognized that this very dramatic faunal demarcation was intimately related to the physical oceanic structure across the Polar Front Zone. His data indicated that (1) cold-water radiolarians are dominant in sediments from a few degrees north of the mean position of the Polar Front to the antarctic margin and (2) a mixed zone containing both warm-water and antarctic radiolarians occurred in sediments for some distance north of the Polar Front. This mixed zone varied between 2 and $7^{\circ}$ in width in a circum-Antarctic traverse. No warm-water radiolarians were found in sediments south of this mixed zone, the southern termination of which coincides with his $90 \%$ isopleth of cold-water antarctic radiolarians (see Hays, 1965, fig. 2).

In the region surrounding Hole 514, data from Hays (1965) and Lozano and Hays (1976) indicated (1) a mean position of the Polar Front Zone at approximately $50^{\circ} \mathrm{S}$ latitude and (2) a mixed zone, about $6^{\circ}$ wide, extending from 47 to $41^{\circ} \mathrm{S}$ latitude, with the $90 \%$ antarctic species isopleth at about $47^{\circ} \mathrm{S}$. Northward through the mixed zone, warm-water species increase in abundance and at some point become the dominant faunal elements.

To examine the late Cenozoic history of the Polar Front as recorded at Hole 514, we compared downhole variations in radiolarian biofacies with their modern spatial distribution relative to the Polar Front, as documented by Hays (1965) and other authors previously mentioned. Our analysis was qualitative; it is intended solely to document major trends in the movement of the Polar Front through time. In Figure 6 four subdivisions of the modern radiolarian distribution can be reliably identified down the core. These include a twofold subdivision of the mixed zone. Labeled 2 on our Figure 6, this portion of the mixed zone is dominated by coldwater antarctic radiolarians, with a southerly termination at the $90 \%$ isopleth of antarctic species. The northern part of the mixed zone, 1 , has reduced numbers of antarctic species and a significant number of warm-water radiolarians. Without detailed quantitative data, the exact latitudinal position of the shift to warm-water radiolarian dominance is arbitrarily taken as the midpoint of the mixed zone north to about $41^{\circ}$. This shift in species dominance in the mixed zone is easily observed down the core. The third biogeographic subdivision of radiolarians refers to the zone south from the $90 \%$ iso-

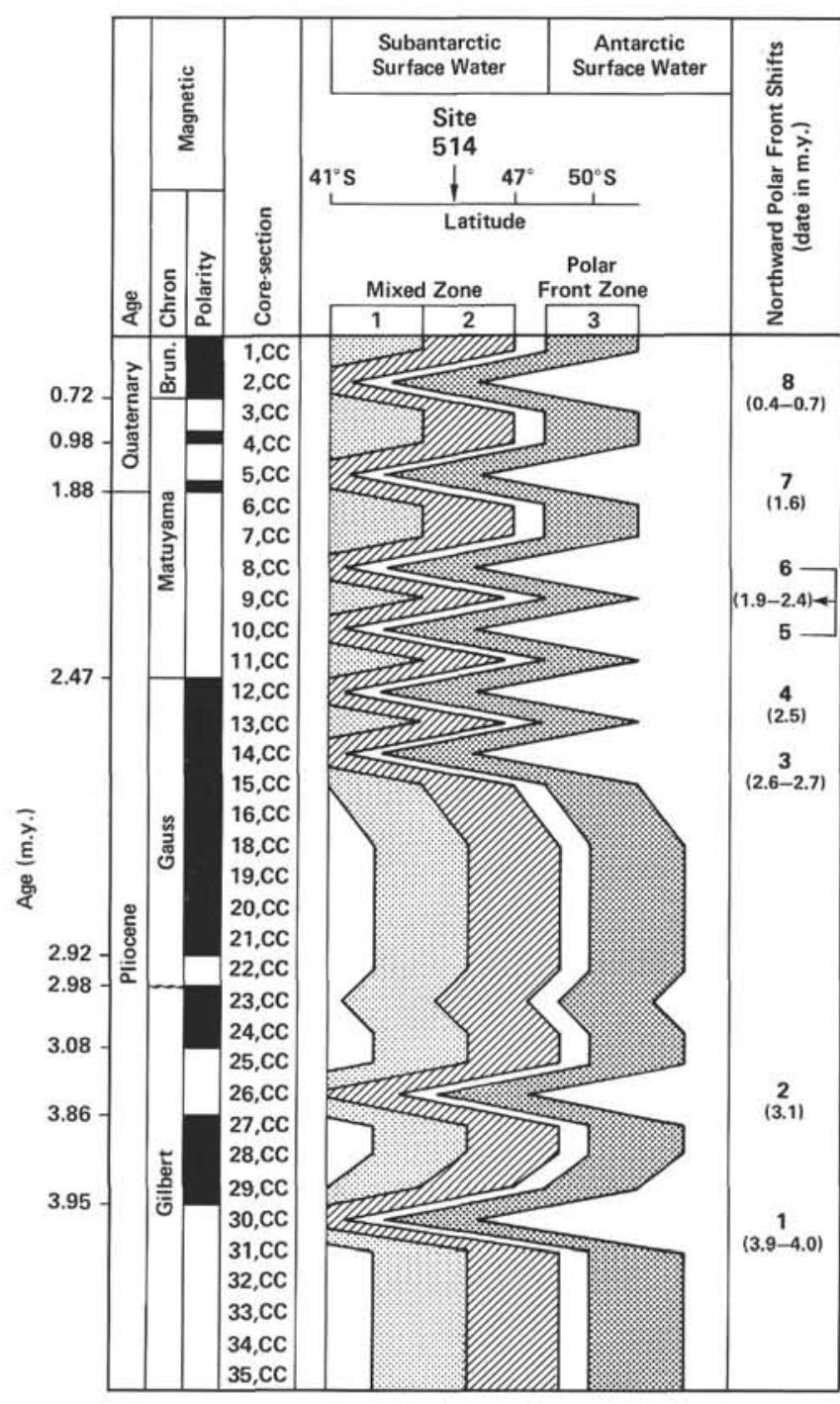

Figure 6. Paleomigrations of the Antarctic Polar Front Zone at DSDP Hole 514 relative to its modern location (see text for explanation).

pleth of antarctic species to the southern termination or extension of the Polar Front Zone. In general, this subdivision centers upon an area at or very near the Polar Front.

Both warm- and cold-water radiolarian species used to document relative Polar Front position through time are listed in Weaver (this volume). Before we present the results of our analysis of Hole 514, several points need to be clarified. Polar Front migrations as recorded in Hole 514 must be evaluated in two intervals, pre- and post-Gauss. The reason, as illustrated by Hays (1965) and Hays and Opdyke (1967), is that there is a major radiolarian faunal change at about 2.5 m.y. which marks a sharp upward decrease in the occurrence of species no longer living in Antarctic waters today. Polar Front migrations before the Gauss Chron must be based on different radiolarian biofacies and therefore several assumptions must be made about subantarctic and antarctic Pliocene radiolarian biogeography and how it is re- 
lated to the position of the Polar Front Zone. These differences and assumptions are discussed in Weaver (this volume).

In Figure 6, we hold the width of the mixed zone and Polar Front Zone constant relative to their modern positions in our downcore analysis. We realize that this is highly unlikely in reality. The mixed zone has been illustrated to compress with a northward shift in the Polar Front (Lozano and Hays, 1976). However, in the absence of any additional cores along a north/south transect, we cannot document the extent of this down the core. Data illustrated in Figure 6 are representative only of the vicinity of Hole 514.

\section{Polar Front Migrations}

Downcore radiolarian assemblage analyses document eight distinct northward shifts in the Polar Front Zone at Hole 514 (Fig. 6).

The first major northward advance of the Polar Front zone occurred at 3.9-4.0 Ma (Sample 514-30,CC). This event is one of considerable magnitude, since 514$31, \mathrm{CC}$ to $514-35, \mathrm{CC}$ are definitely in the mixed zone and contain numerous warm-water radiolarian species. On the other hand, radiolarians in Sample 514-30,CC consist of cool-water species endemic to waters at or south of the Polar Front. This late Pliocene Polar Front shift is most likely a product of regional climatic deterioration in the subantarctic and antarctic region towards the end of the Gilbert, beginning at 4.6-4.4 Ma and terminating with a major northward shift in the ephemeral sea-ice front around Antarctica and a major glacial episode in Argentinian Patagonia at 3.59 Ma (Mercer, 1974; Mercer et al., 1975; Weaver, 1973). Late Gilbert climatic cooling has been documented by several authors using both paleontological and sedimentological criteria (Weaver, 1976; Keany, 1978; Bandy et al., 1971; Ciesielski et al., 1982).

A second northerly shift in the Polar Front is observed in Sample 514-26,CC, coincident with or slightly above a hiatus between Cores 26 and 27 that spans about $0.674 \mathrm{~m}$.y. In the absence of any lower Gauss and uppermost Gilbert sediments, it is difficult to evaluate the regional significance of this Polar Front shift. It is very difficult to identify the hiatus paleontologically and at present we are not positive that Sample 514$26, \mathrm{CC}$ is not late Gilbert in age $(\sim 3.85 \mathrm{Ma})$.

The third major Pliocene Polar Front shift observed in Hole 514 occurs at 2.7-2.6 Ma, between Cores 18 and 14 , and documents the passing of a critical climatic threshold discussed by Kennett (1978); after this event the earth exhibited glacial oscillations reflecting Northern Hemisphere ice-sheet development and melting (Kennett, 1982). This interval documents the maximum development of the first Northern Hemisphere ice sheets during the Pliocene. According to Kennett (1982), after this time the amplitude and frequency of Northern Hemisphere ice-sheet fluctuations increase through the late Pliocene and Quaternary. Considerable evidence has documented the global cooling and initiation of Northern Hemisphere Pliocene glaciation that began at about 3.2-3.0 $\mathrm{Ma}$ and terminated in the formation of the Northern Hemisphere ice caps by mid to late Gauss (Shackleton and Opdyke, 1977; Weaver, 1973; Ciesielski et al., 1982; Kennett, 1978, 1982; Berggren, 1972; Stainforth et al., 1975).

The remaining five northward shifts in the Polar Front Zone shown in Figure 6 span the latest Pliocene and Quaternary. These shifts represent climatic cooling events in subantarctic and antarctic regions and may be synchronous on a global scale with Northern Hemisphere glacial pulses.

The magnitude of the eight northerly shifts of the Polar Front documented at Hole 514 is difficult to ascertain in the absence of any additional time-equivalent core material to the north and south of Hole 514. In comparison with the modern position of the Polar Front, it appears to us that these Polar Front movements we observe are on the order of $4^{\circ}$ latitude. This magnitude is consistent with data presented by Lozano and Hays (1976), who document a $7^{\circ}$ northward shift in the Polar Front in the western Atlantic at the 18,000 y.B.P.glacial maximum.

\section{Pliocene-Pleistocene Ice-Rafting (Table 1)}

Sites 513 and 514 provide a composite record of Pliocene-Pleistocene ice-rafting into the Southwest Atlantic, with the exception of the late Gilbert through early Gauss Chron, which is missing at both sites. Bornhold (this volume) identified four zones of IRD in Hole 513 and six zones in Hole 514. In general the Pliocene zones of IRD accumulation in Hole 513, the more southerly of the two sites $\left(47^{\circ} 34.99^{\prime} \mathrm{S}\right)$, encompass larger intervals of time than at Hole $514\left(46^{\circ} 02.77^{\prime} \mathrm{S}\right)$ where IRD accumulated in zones for which time spans were $120,000 \mathrm{y}$.

Table 1. Major zones of IRD accumulation in Holes 513, 513A, and 514 (after Bornhold, this volume).

\begin{tabular}{|c|c|c|c|}
\hline IRD Zone & $\begin{array}{l}\text { Sub- } \\
\text { bottom } \\
\text { Depth } \\
\text { (m) }\end{array}$ & $\begin{array}{l}\text { Core/Section } \\
\text { or Sample } \\
\text { (level in } \mathrm{cm} \text { ) }\end{array}$ & $\begin{array}{l}\text { Age }(\mathrm{Ma}) \text { and } \\
\text { Paleomagnetic Correlation }\end{array}$ \\
\hline \multicolumn{4}{|l|}{ Holes $513-513 \mathrm{~A}$} \\
\hline 1 & 131-118 & $513-5-6$ to $513 \mathrm{~A}-6-3$ & -5.57-5.43; mid-Chron 5 \\
\hline 2 & 106.5 & $513 \mathrm{~A}-5-2,100 \mathrm{~cm}$ & -5.35; late normal portion of Chron 5 \\
\hline 3 & 85.0 & $513-9-6,150 \mathrm{~cm}$ & -4.60 ; Thvera Subchron of Gilbert Chron \\
\hline 4 & $76-56$ & $\begin{array}{l}513-9-1,50 \mathrm{~cm} \text { to } \\
513-6-1,150 \mathrm{~cm}\end{array}$ & $\begin{array}{l}-4.35-3.85 \text { and }-3.10-2.22 ; \text { Cochiti and } \\
\text { Nunivak subchrons and mid-Gauss to } \\
\text { carly Matuyama }\end{array}$ \\
\hline 5 & $47-38$ & $\begin{array}{l}513-5, \mathrm{CC} \text { to } \\
513-5-1,50 \mathrm{~cm}\end{array}$ & $\begin{array}{l}2.15-1.70 \text {; early Matuyama through } \\
\text { Olduvai Subchron }\end{array}$ \\
\hline 6 & $30-20$ & $\begin{array}{l}513-4-2,50 \mathrm{~cm} \text { to } \\
513-3-1,150 \mathrm{~cm}\end{array}$ & $\begin{array}{l}\text { 1.5-0.95; late Matuyama Chron, after } \\
\text { Olduvai Subchron }\end{array}$ \\
\hline 7 & $7.5-0$ & $\begin{array}{l}513-1-5,150 \mathrm{~cm} \text { to } \\
\text { surface }\end{array}$ & - 0.4-present; Brunhes Chron \\
\hline \multicolumn{4}{|l|}{ Hole 514} \\
\hline I & $143-134$ & $\begin{array}{c}34-1,100 \mathrm{~cm} \text { to } \\
32-1,80 \mathrm{~cm}\end{array}$ & $\begin{array}{l}4.07-4.01 \text {; between Cochiti and Nunivak } \\
\text { subchrons }\end{array}$ \\
\hline II & $129-124$ & $\begin{array}{r}31-1,20 \mathrm{~cm} \text { to } \\
29-3,100 \mathrm{~cm}\end{array}$ & $\begin{array}{l}\text { 3.98-3.94; prior to Cochiti to within } \\
\text { Cochiti Subchron }\end{array}$ \\
\hline III & $83-75$ & $\begin{array}{r}20-2,110 \mathrm{~cm} \text { to } \\
18-3,40 \mathrm{~cm}\end{array}$ & 2.86-2.78; late normal Gauss Chron \\
\hline IV & $68-56$ & $\begin{array}{r}17-1,80 \mathrm{~cm} \text { to } \\
14-2,50 \mathrm{~cm}\end{array}$ & 2.71-2.59; late normal Gauss Chron \\
\hline $\mathrm{v}$ & $35-31$ & $\begin{array}{c}9-2,150 \mathrm{~cm} \text { to } \\
8-3,40 \mathrm{~cm}\end{array}$ & $\begin{array}{l}\text { 2.22-2.12; early Matuyama prior to } \\
\text { Olduvai Subchron }\end{array}$ \\
\hline VI & $22-0$ & $\begin{array}{l}6-3,20 \mathrm{~cm} \text { to } \\
\text { surface }\end{array}$ & $\begin{array}{l}\text { 1.89-Present; early Olduvai Subchron- } \\
\text { Brunhes Chron }\end{array}$ \\
\hline Subzone A & $9.23-8.10$ & $\begin{array}{l}3-3,63 \mathrm{~cm} \text { to } \\
3-2,100 \mathrm{~cm}\end{array}$ & $\begin{array}{l}\text { 0.77-0.71: latest Matuyama Chron-earliest } \\
\text { Brunhes Chron }\end{array}$ \\
\hline Subzone B & 7.6-6.9 & $\begin{array}{l}3-2,50 \mathrm{~cm} \text { to } \\
3-1,130 \mathrm{~cm}\end{array}$ & 0.69-0.65: earliest Brunhes Chron \\
\hline
\end{tabular}


or less. In addition, Pliocene abundances of IRD $(\mathrm{mg} / \mathrm{g})$ and IRD accumulation rates $\left(\mathrm{mg} / \mathrm{cm}^{2} \cdot 10^{3} \mathrm{y}\right.$.) are generally higher at Site 513 than at Site 514 .

Only Hole 513 contains Pliocene sediment of the Nunivak Subchron or older (4.08-5.26 Ma) and in this hole Pliocene IRD first occurs, in Sample 513-9-6, $150 \mathrm{~cm}$. This interval of IRD occurrence, Zone 3, is represented by a single sample with IRD abundance of the same order of magnitude as noted in the Miocene of Site 513. IRD Zone 4 occurs between 513-9-1, $50 \mathrm{~cm}$ and 513-6-1, 150 $\mathrm{cm}$, bracketing the hiatus that falls within the late Gilbert to early Gauss chrons. The portion of the zone below the hiatus is assigned to the Gilbert Chron and is approximately $4.35-3.85 \mathrm{Ma}$, whereas the portion of the IRD Zone above the hiatus is mid-Gauss to early Matuyama Chron, $\sim 3.10-2.22 \mathrm{Ma}$. Thus, with a $674,000 \mathrm{y}$. hiatus within IRD Zone 4, it is impossible to determine whether or not the interval from 4.35 to $2.22 \mathrm{Ma}$ was a period of continuous IRD deposition at Site 513 or if the zone represents two discrete periods of IRD deposition juxtaposed by the hiatus. In either event, the late Gilbert Chron heralds a major and permanent change in the pattern of ice-rafting in the South Atlantic. After 4.35 Ma, the frequency of major episodes of IRD accumulation increases, as do the abundance and accumulation rates of IRD.

As we have shown in Figure 5, the late Gilbert and Gauss Chronozone record in Hole 514 is punctuated by a hiatus of duration similar to that found at Hole 513. A comparison of age-equivalent sediment from Holes 513 and 514 ( $4.07 \mathrm{Ma}$-present) reveals that during the time IRD Zone 4 was deposited at Hole 513, four more brief episodes of IRD accumulation occurred at Hole 514 (Zones I, II, III, and IV of Bornhold, this volume). Based on the average sedimentation rates, calculated from the depths of paleomagnetic boundaries, these IRD zones have a maximum duration of $120,000 \mathrm{y}$. (Zone IV) and a minimum duration of $40,000 \mathrm{y}$. IRD Zones I (4.07-4.0 Ma) and II (3.98-3.94 Ma) occur below the Pliocene hiatus of Hole 514; both zones are partially correlative to the portion of Hole 513 IRD Zone 4 which occurs below the mid-Pliocene hiatus. IRD Zones III (2.86-2.78 Ma) and IV (2.71-2.59 Ma) of Hole 514 are bracketed by the portion of IRD Zone 4 $(\sim 3.10-2.22 \mathrm{Ma})$ above the mid-Pliocene hiatus of Hole 513.

IRD Zone V (2.22-2.12 Ma) of Hole 514 is the youngest of the Pliocene IRD zones. This early Matuyama IRD Zone has no counterpart at Site 513. As IRD deposition terminated at Hole $514(2.12 \mathrm{Ma})$ the locus of IRD deposition apparently shifted southward to Hole 513 where IRD Zone 5 was deposited throughout the remainder of the Pliocene and into the Pleistocene (2.15$1.70 \mathrm{Ma})$.

Bornhold (this volume) found IRD consistently present throughout the Pleistocene of Hole 514 and designated this interval as IRD Zone VI (1.89 Ma-present). Three discrete zones of high IRD accumulation were noted in the Pleistocene of Hole 513; Zone 5, which brackets the Pliocene-Pleistocene boundary, Zone 6 (1.5-0.95 Ma), and Zone 7 (0.4 Ma-present). Both sites exhibit large-scale variation in IRD accumulation rates. These rates were higher at Hole 514 during the Matuyama Chron than during any equivalent time span, earlier or later; however, Brunhes IRD accumulation rates at Site 514 are lower than at Site 513.

\section{Relationship of Polar Front Migrations to IRD Accumulation Zones}

The Polar Front Zone (PFZ) is a physical oceanic boundary separating subantarctic and antarctic surface waters where sea surface temperatures rise abruptly. Because of the rapid temperature increase and latitudinal current drift within the Polar Front Zone this boundary serves as a barrier to the northward drift of most Southern Ocean icebergs. In addition, this zone is probably the region of the lower latitudes of the Southern Ocean where the maximum IRD accumulation rates occur because of the rapid melting of icebergs within the Polar Front Zone. Thus a comparison of the previously discussed history of Polar Front migrations and IRD accumulation at Hole 514 should provide additional insight into late Pliocene-Pleistocene paleoceanography of the region.

The first major migration of the Polar Front northward over Hole 514 (3.9-4.0 Ma) is preceded by several periods of IRD accumulation at Hole 514 and 513: Zone 1 to lower Zone 4 of $513(\sim 5.57-3.85 \mathrm{Ma})$ and Zone I of Hole $514(4.07-4.01 \mathrm{Ma})$. Thus it appears that the PFZ had migrated as far north as Hole 513 by Chron 5 time, maintained a position between Hole 513 and 514 from mid-Chron 5 through the late Gilbert Chron, and finally migrated to a position just south of Hole 514 by $4.07 \mathrm{Ma}$.

The first recorded major migration of the PFZ to a position north of Hole 514 occurred at $\sim 3.9-4.0 \mathrm{Ma}$ and is accompanied by the deposition of IRD Zone II (3.98-3.94 Ma) and the oldest ice-rafted clast (3.9 Ma) noted in Hole 514. Large variations occur in the IRD accumulation rates at both sites over intervals representing only tens of thousands of years. Rapid migrations of the PFZ during the late Gilbert must be partially responsible for these variations; other factors such as variations in iceberg tracks and the volume of berg production must also have been influential.

The portion of the Gilbert Chron after the Cochiti Subchron and the early Gauss Chron is unrepresented at Holes 513 and 514, as well as Holes 511 and 512. A major increase in the velocity of the Antarctic Circumpolar Current (ACC) at this time apparently led to a Southern-Ocean-wide erosional event by the Circumpolar Deep Water, the agent of erosion at Holes 511 and 512, and by Antarctic Bottom Water (AABW), the agent of erosion at Holes 513 and 514 (Ciesielski et al., 1982; Ledbetter and Ciesielski, 1982; Osborn et al., in press). Correlative with this major erosional period was a major northward displacement of the boundary between the glacial marine and siliceous ooze sedimentary regimes off the Adelie coast of East Antarctica after 3.86 Ma to a position north of its present position (Weaver, 1973). Thus even though the latest Gilbert-early Gauss record 
is absent in Leg 71 sediments the position of the PFZ at this time must have been north of its present position and Hole 513, perhaps as far north as Hole 514.

The siliceous faunas of the mid-Gauss sediment above the aforementioned hiatus verify a PFZ position in the vicinity of Hole 514 at $\sim 3.1 \mathrm{Ma}$; thereafter the PFZ retreated south until the latest Gauss when it advanced northward once again at $\sim 2.7-2.6 \mathrm{Ma}$. The proposed position of the PFZ south of Hole 514 during this intervening interval is consistent with the Hole 514 IRD record. Only one brief episode of IRD accumulation (Zone III) occurred at Site 514 between 3.1 and $2.6 \mathrm{Ma}$. It is possible this IRD zone was deposited during a brief migration of the PFZ over the site but was unrecognized in our Polar Front migration study because of our wide sample spacing. During much of the late Gauss the Polar Front was apparently in a more southerly position in the vicinity of Site 513 , thus accounting for the more abundant and prolonged deposition of IRD in the vicinity of this site during the late Gauss (IRD Zone 4, 3.10$2.22 \mathrm{Ma}$ ).

Between 2.6 and $2.7 \mathrm{Ma}$ a major change occurred in the frequency of PFZ migrations over Site 514. Even with our wide sample spacing we record twelve movements of the PFZ northward or southward over the site. Large-scale fluctuations in the IRD accumulation rates at Sites 513 and 514, from as much as 200 to less than 10 $\mathrm{mg} / \mathrm{cm}^{2} \cdot 10^{3} \mathrm{y}$., may certainly be in response to the repeated fluctuations in the position of the PFZ relative to these sites. As expected, lowest IRD accumulation rates appear to have occurred when the PFZ was to the south of the sites and significantly higher IRD accumulation rates occurred south of the PFZ. In these latitudes the highest rates of IRD accumulation occur within the PFZ.

Five samples from the Matuyama Chronozone of Hole 514 exhibit IRD accumulation rates greater than any Matuyama samples analyzed from Hole 513 (Bornhold, this volume). The opposite relationship is true for Brunhes-age samples, which almost all have higher IRD accumulation rates than those from Hole 513. We interpret these relationships to signify that the mean position of the PFZ was closer to the more northerly Site 514 during much of the Matuyama Chron, but further to the south, closer to Site 513, throughout much of the Brunhes Chron. The maximum early Matuyama northward advances of the PFZ, to a position north of Site 514, occurred at a time when the ACC was greatly intensified. Osborn et al. (in press) found that the maximum frequency of hiatuses in the southeast Indian Ocean during the last 3.5 m.y. occurred during the mid to late Matuyama. At that time a similar peak in the frequency of hiatuses occurred in the South Atlantic sector of the Southern Ocean in response to intensification of the ACC and its associated deep water masses, the Circumpolar Deep Water and AABW (Ciesielski and Ledbetter, unpublished data; Ciesielski et al., 1982; Ledbetter and Ciesielski, 1982). Recent studies reveal that during the Brunhes Chron bottom-current activity was less intense than in the mid to late Matuyama in the South Atlantic and southeast Indian oceans (Osborn et al., in press; Ciesielski and Ledbetter, unpublished data).

\section{MIOCENE PALEOENVIRONMENT}

\section{Miocene Ice-Rafting (Tables 1 and 2)}

The Leg 71 Miocene sedimentary record is based solely on Holes 512 and 513A. Upper middle to lower upper Miocene sediments of Site 512 are devoid of sand-sized IRD and ice-rafted clasts (Bornhold, this volume). The younger upper Miocene sediments of Site 513 do, however, contain minor amounts of IRD. The lowermost occurrence of IRD of any kind occurs in Section 51310-1, where a clast is present, apparently in place. This clast is probably only slightly younger than the $8.7 \pm$ $0.2 \mathrm{~m} . \mathrm{y}$. old volcanic ash found in Section 6 of the same core and is therefore assigned an age of $\sim 8.7 \mathrm{Ma}$.

Three other occurrences of IRD are noted in the Miocene of Hole 513A. Another ice-rafted clast occurs in Hole $513 \mathrm{~A}$, at a sub-bottom depth of 122.4 meters, in sediment we correlate to the early reversed portion of Chron $5(\sim 5.57 \mathrm{Ma})$. The oldest occurrence of sandsized IRD also occurs in Hole 513A sediments of Chronozone $5(\sim 5.57-5.43 \mathrm{Ma})$, IRD Zone 1. IRD Zone 2 of Hole 513 occurs in uppermost Chronozone $5(\sim 5.35$ $\mathrm{Ma})$. IRD accumulation rates and grains/g are lower in IRD Zone 1 than Zone 2; only 2 grains/g were noted in Zone 1 .

The 8.7 m.y. old ice-rafted clast found in Hole 513A is the oldest evidence of ice-rafting to the lower latitudes of the Southern Ocean. Even though Chron 7 and 8 sediments are not represented in Hole 513A, it does not appear likely that any significant ice-rafting occurred, for some of it would be expected to be present as residual lag at the disconformable boundary between Chronozone 6 and 9 sediments (between 513A-9-1 and 513A-101); none, however, was found at this level. Levels of Chronozone 5 ice-rafting in IRD Zones 1 and 2 are minor in comparison with the IRD accumulation rates of the Pliocene and Pleistocene, where maximum abundance peaks are orders of magnitude greater than during the Miocene.

\section{Miocene Unconformities (Fig. 7-9; Ciesielski, this volume, Fig. 9)}

Three disconformities occur in the Miocene of Hole $513 \mathrm{~A}$, two within the upper Miocene and the third in the

Table 2. Occurrence of IRD clasts in Holes 513 and 514.

\begin{tabular}{|c|c|c|}
\hline $\begin{array}{c}\text { Core/Section or } \\
\text { Sample } \\
\text { (interval in } \mathrm{cm} \text { ) }\end{array}$ & $\begin{array}{l}\text { Sub-bottom } \\
\text { Depth }(\mathrm{m})\end{array}$ & $\begin{array}{c}\text { Age (Ma) and } \\
\text { Paleomagnetic Correlation }\end{array}$ \\
\hline $13 \mathrm{~A}-10-1$ & $152-153$ & 8.7; late Chron 9 \\
\hline $513 \mathrm{~A}$ & 122 & $\begin{array}{l}\text { 5.57; early reversed portion of } \\
\text { Chron } 6\end{array}$ \\
\hline $513 A-4-5,23-25$ & $100.73-100.75$ & 5.00; earliest Gilbert Chron \\
\hline $513 \mathrm{~A}-$ & 59.2 & $\begin{array}{l}\text { 3.90; Cochiti Subchron of } \\
\text { Gilbert Chron }\end{array}$ \\
\hline $513-5-4,32-36$ & 42.35 & $\begin{array}{l}\text { 1.88; early Olduvai Subchron of } \\
\text { Matuyama Chron }\end{array}$ \\
\hline $513-4-6,86-87$ & $36.36-36.37$ & $\begin{array}{l}\text { 1.66; late Olduvai Subchron of } \\
\text { Matuyama Chron }\end{array}$ \\
\hline 514 , Cores 1-3 & $9.5-0$ & $\begin{array}{l}\text { 0.78-present; latest Matuyama } \\
\text { Chron-Brunhes Chron }\end{array}$ \\
\hline $513-1-2,109-110$ & $1.60-1.59$ & $\sim 0.10$; latest Brunhes Chron \\
\hline
\end{tabular}




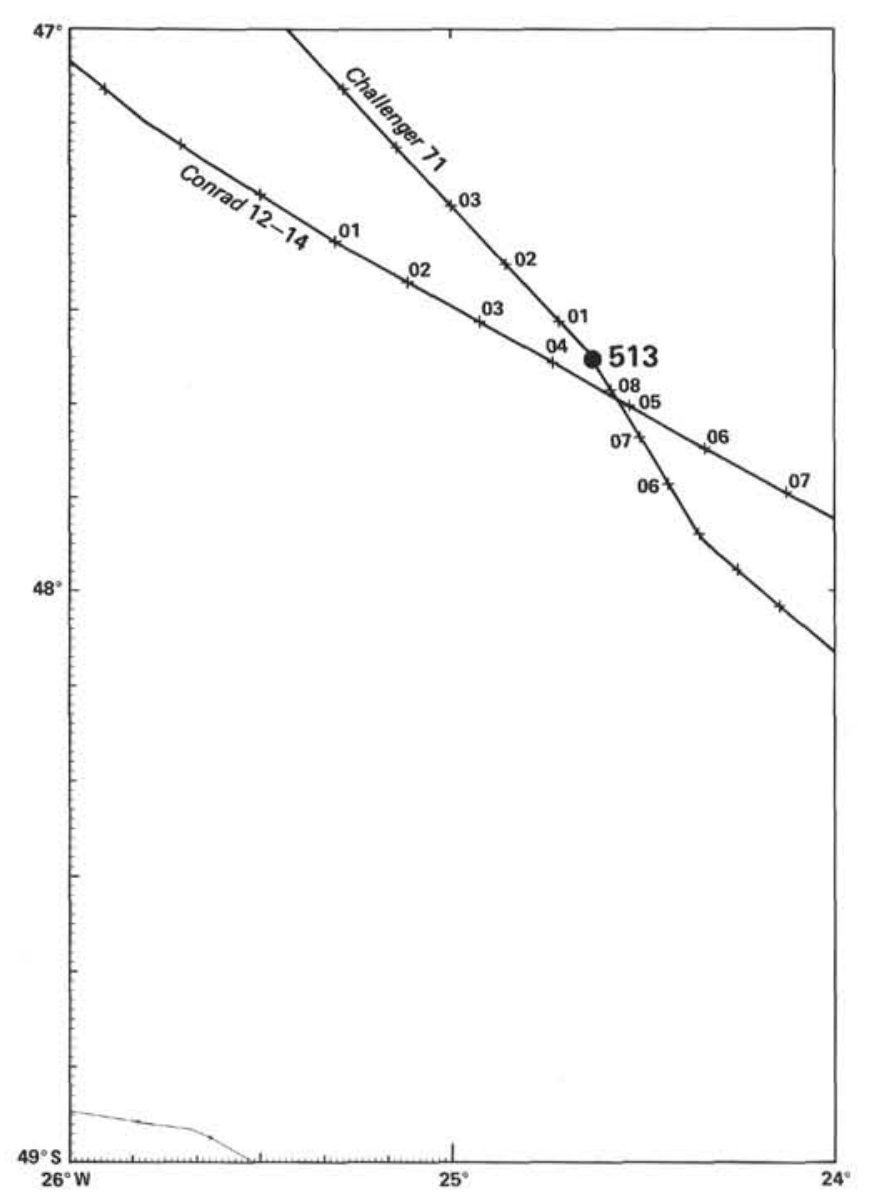

Figure 7. Location of Hole 513 with respect to the seismic reflection profiles of Figures 8 and 9. Numbers on the ship tracks refer to hours. (Provided by W. J. Ludwig.)

middle lower to lower upper Miocene. The shallowest of these hiatuses occurs between Cores 4 and 5 and, based on our comparison of this interval with Islas Orcadas piston core 7-2, represents only a portion of uppermost Chronozone 5. The second upper Miocene disconformity, between Samples 513A-9-1, 69-71 cm and 513A-10-1, 13-15 cm, encompasses most or all of Chronozones 7 and 8 .

The oldest Miocene disconformity detected in Leg 71 sediments occurs within Hole $513 \mathrm{~A}$ between Samples 513A-12-1, 9-11 cm and 513A-12-1, 123-125 cm (Gombos and Ciesielski, this volume, Fig. 5). This disconformity separates the lower portion of the upper Miocene Denticulopsis hustedtii/D. lauta diatom Zone from the middle portion of the lower Miocene Coscinodiscus rhombicus diatom Zone. We estimate the hiatus to represent approximately $8 \mathrm{~m} . y$. , extending from $\sim 9.5$ or 10.0 to $\sim 18.0-18.5 \mathrm{Ma}$.

The sedimentology and micropaleontology of sediments in Core $513 \mathrm{~A}-11$ provide evidence that the erosion which produced this major disconformity in Hole 513A was widespread. Abundant reworked diatoms are present in sediments immediately above the disconformity (Ciesielski, this volume, Table 3 ) in the interval between 513A-12-1, 9-11 cm and 513A-11-2, 120-122 $\mathrm{cm}$. Reworked diatoms in this interval are accompanied by common rip-up clasts of up to $1 \mathrm{~cm}$ and the grayish brown color is indicative of oxidative conditions. Above 513A-11-2, 120-122 cm the sediment color changes to greenish gray, rip-up clasts disappear, and reworked microfossils become much less frequent. The size and abundance of rip-up clasts and microfossils immediately above the disconformity suggests that the source of the reworked microfossils and rip-up clasts was close by.

Seismic reflection profile records were examined by W. J. Ludwig and Ciesielski to determine if any of the Miocene disconformities are of regional extent. Initially we examined the Challenger track over Site 513 and the Conrad 12-14 track immediately south of the site (Fig. 7). A prominent reflector (identified by the symbol " $U$ " in Fig. 8) was found to occur at the same sub-bottom depth in Hole 513A as the lower upper Miocene to upper lower Miocene hiatus. This reflector can be traced continuously to the southeast and northwest of Site 513 (Fig. 9) along the Conrad and Challenger tracks. Only a few kilometers to the southeast of the site the erosional surface outcrops (Fig. 8); in this region most sediment above the lower Miocene appears to have been removed by erosion. To the northwest the " $U$ " reflector appears to be continuous into the Argentine Basin; however, it cannot be reliably traced as far as Site 514 because of interruptions by basement highs and a much thicker sedimentary sequence.

Our examination of other Vema and Conrad seismic reflection profiles to the southwest of Site 513 suggests that the "U" reflector is of regional extent (Fig. 9). North of the Falkland Fracture Zone and east of the Islas Orcadas Rise a major reflector present at a similar sub-bottom depth has characteristics similar to the "U" reflector in the vicinity of Site 513 . This reflector can be traced to within $65 \mathrm{~km}$ of Site 513 and probably represents the same upper lower Miocene to lower upper Miocene hiatus. Thus most of the region between the lower flank of the Mid-Atlantic Ridge and Islas Orcadas Rise and the southeast Argentine Basin suffered one or more major erosional episodes between $\sim 18.5$ and $9.5 \mathrm{Ma}$. Since the depth of the entire region is greater than 4000 meters, the agent of erosion and/or deposition must have been AABW.

Although the regional hiatus represents $\sim 10$ m.y., there is evidence that much of the erosion may have taken place during the early late Miocene. With the Chron 9 resumption of deposition at Site 513, abundant transported rip-up clasts and reworked microfossils were deposited immediately above the disconformity (513A-12$1,9-11 \mathrm{~cm}$ through $513 \mathrm{~A}-11-2,120-122 \mathrm{~cm}$ ), signifying that although bottom currents had waned sufficiently at Site 513 to allow deposition, AABW velocity was still great enough to cause considerable erosion in the vicinity. Reworked diatoms and silicoflagellates above the hiatus represent most biostratigraphic zones of the missing upper lower to lower upper Miocene interval, suggesting that a great deal of the erosion that created the regional disconformity may have occurred during Chron 9 of the late Miocene. 


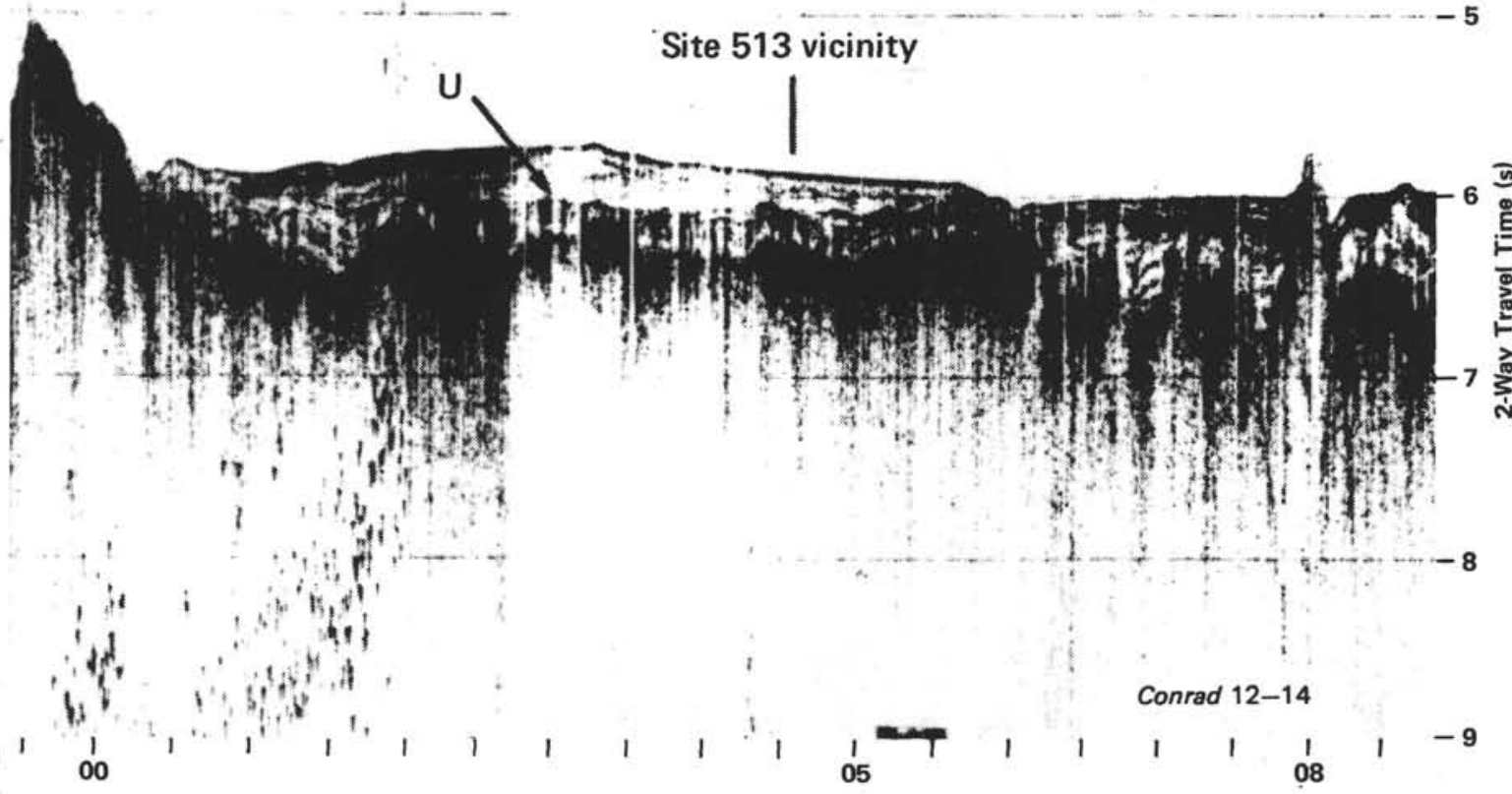

B South

North_4

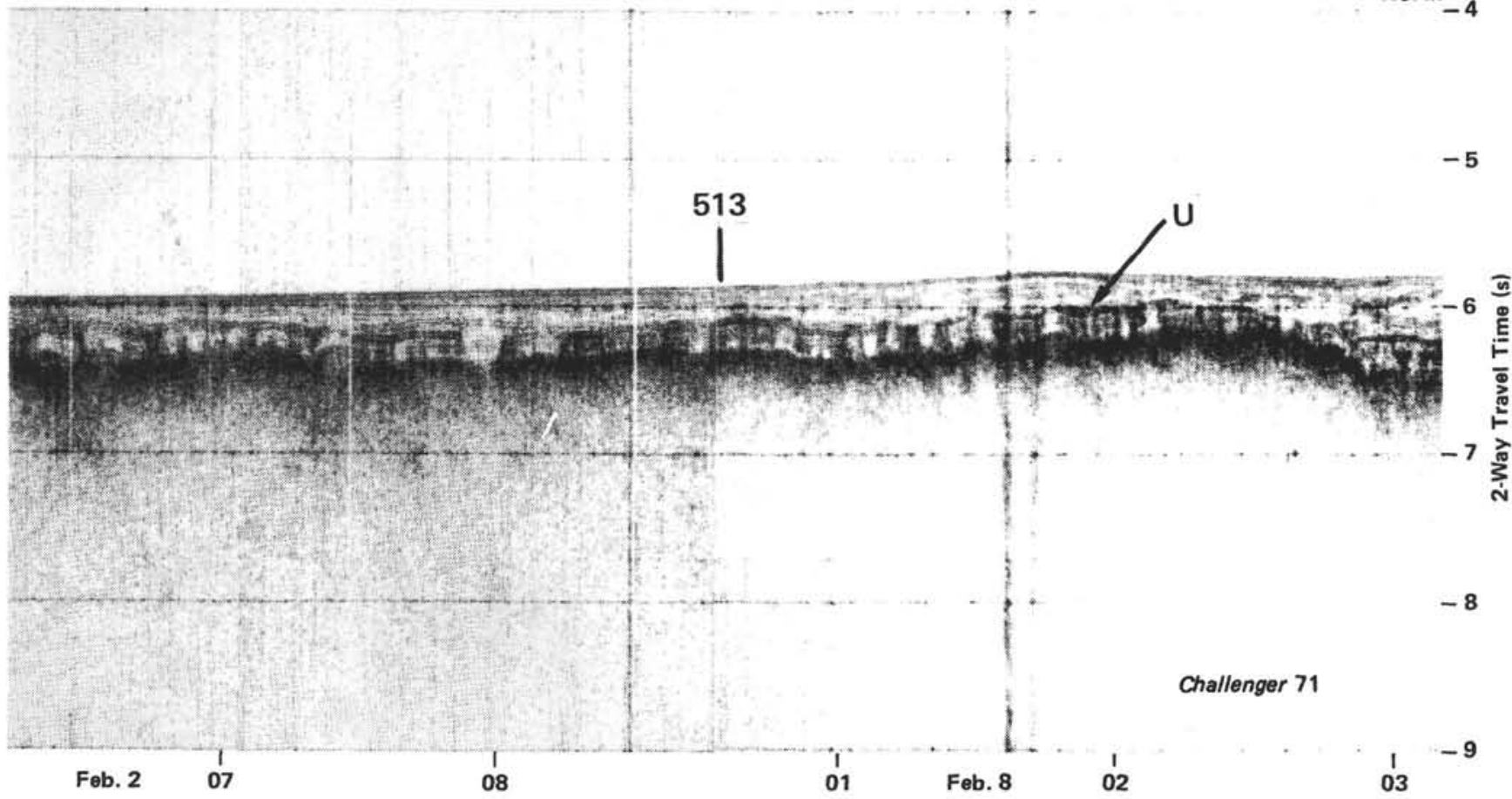

Figure 8. Seismic reflection profiles of Conrad (A) and Glomar Challenger (B) over Site 513. The reflector identified by "U" is a regional Miocene unconformity. (Provided by W. J. Ludwig.)

Late Miocene Paleoenvironment of the Southern Ocean (Figs. 10 and 11, Table 3)

Ciesielski et al. (1982) recently reviewed a wide range of evidence regarding Miocene glacial, climatic, and oceanic conditions of the Antarctic circumpolar region.
Herein we will attempt to interpret the upper Miocene sedimentary record of Leg 71 sites by examining in greater detail the temporal and geographic distribution of Oligocene-Quaternary IRD and biosiliceous sedimentary facies at most pelagic drill sites of the Southern Ocean (Fig. 10). To accomplish this, the upper middle Miocene 


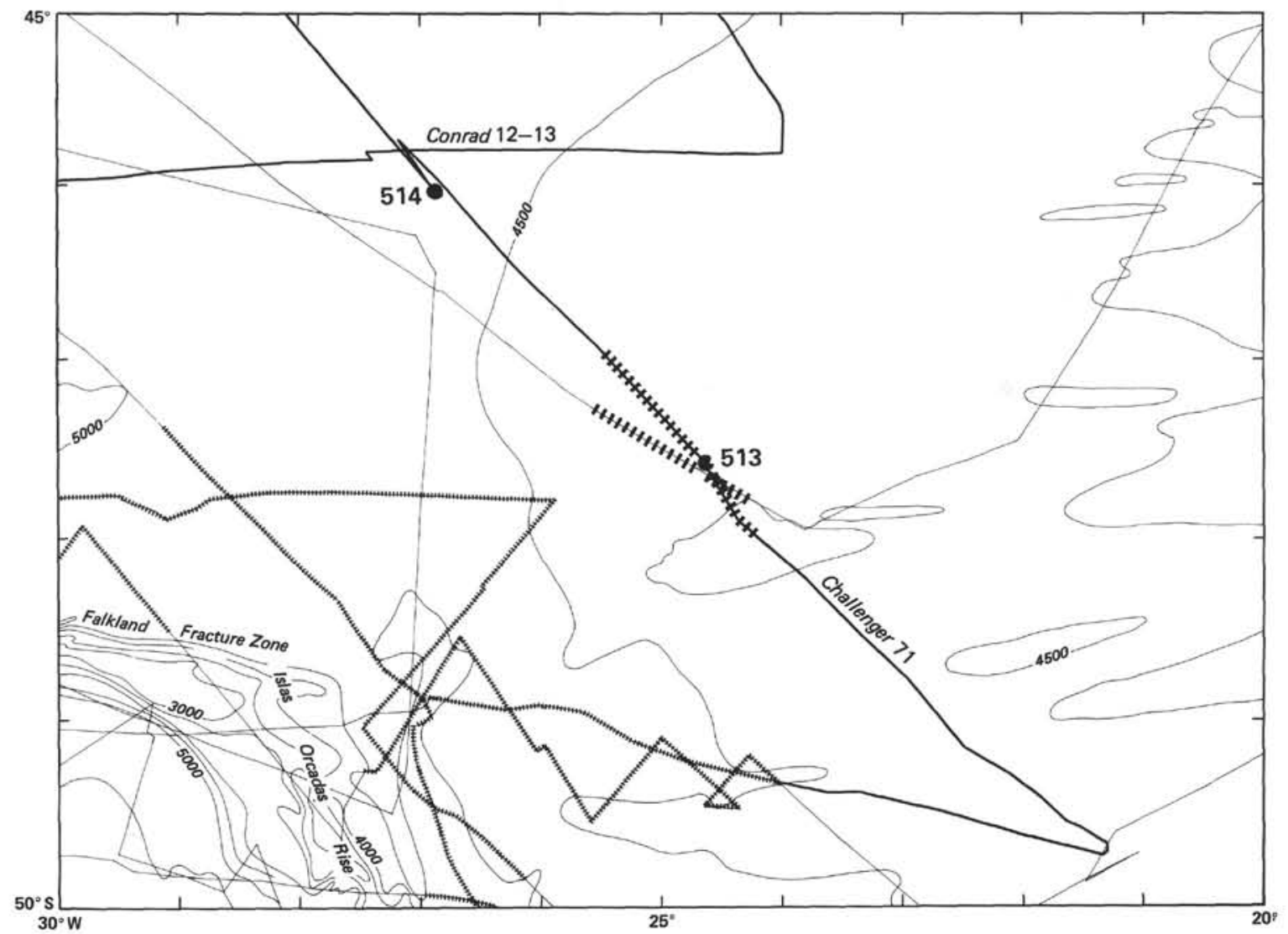

Figure 9. Southwest Atlantic in the vicinity of Sites 513 and 514, with seismic reflection track lines. Bold hachure on the track line near Site 513 indicates the extent of the Miocene unconformity that can be confidently traced to Site 513. Smaller hachure on track lines indicates areas where the same unconformity is recognized in seismic reflection profile records. (Prepared by P. F. Ciesielski and W. J. Ludwig.)

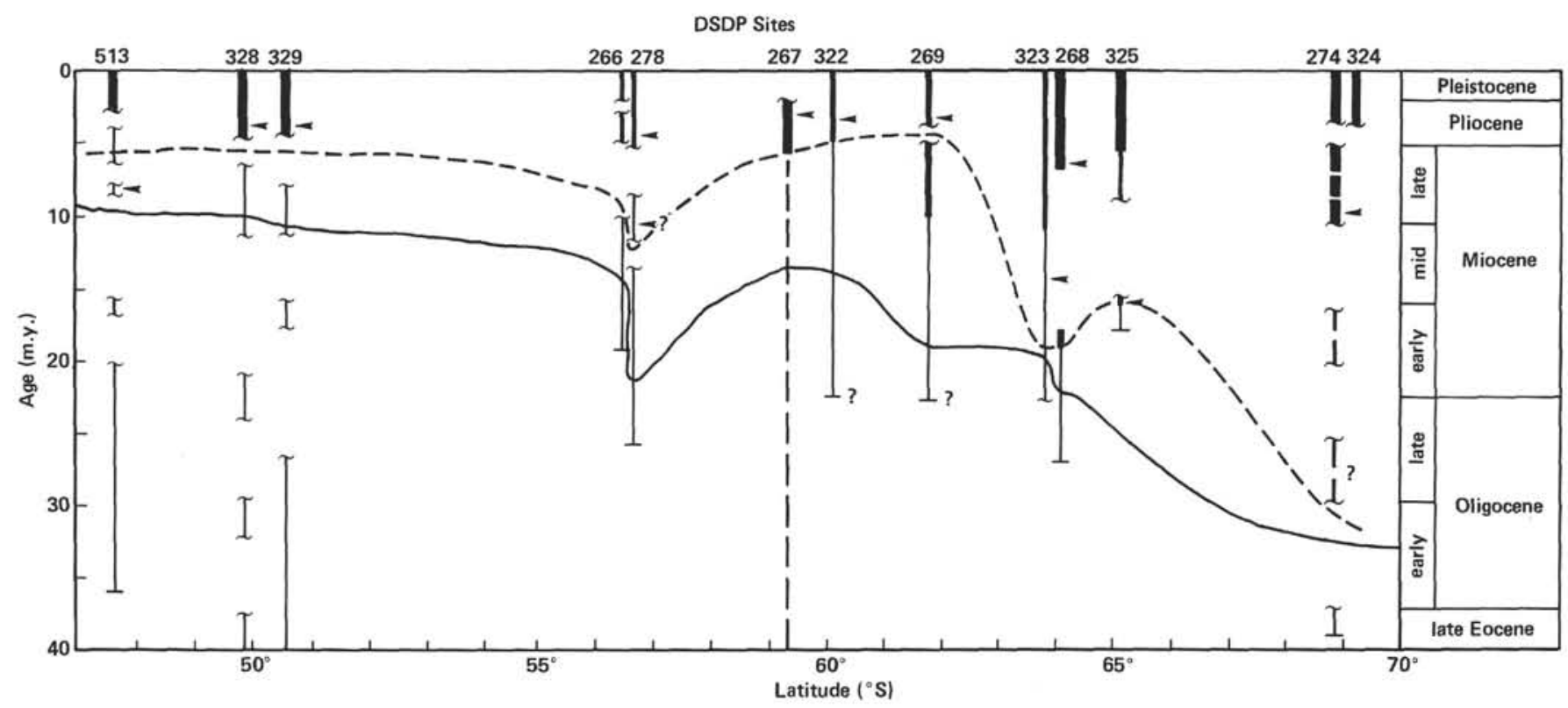

Figure 10. Distribution of IRD and biogenic silica in the Southern Ocean during the late Paleogene and Neogene. Vertical lines represent the temporal distribution of DSDP sedimentary sequences. Arrows indicate the first occurrence of ice-rafted clasts. Bold portions of vertical columns represent an order of magnitude increase in sand-sized IRD. Dashed line signifies the lower limit of significant sand-sized IRD. Area between the curved lines represents temporal and geographic distribution of biogenic siliceous sediment. Ages of DSDP sedimentary sequences corrected according to the diatom zonations of Weaver and Gombos (1981) and Ciesielski (this volume). 


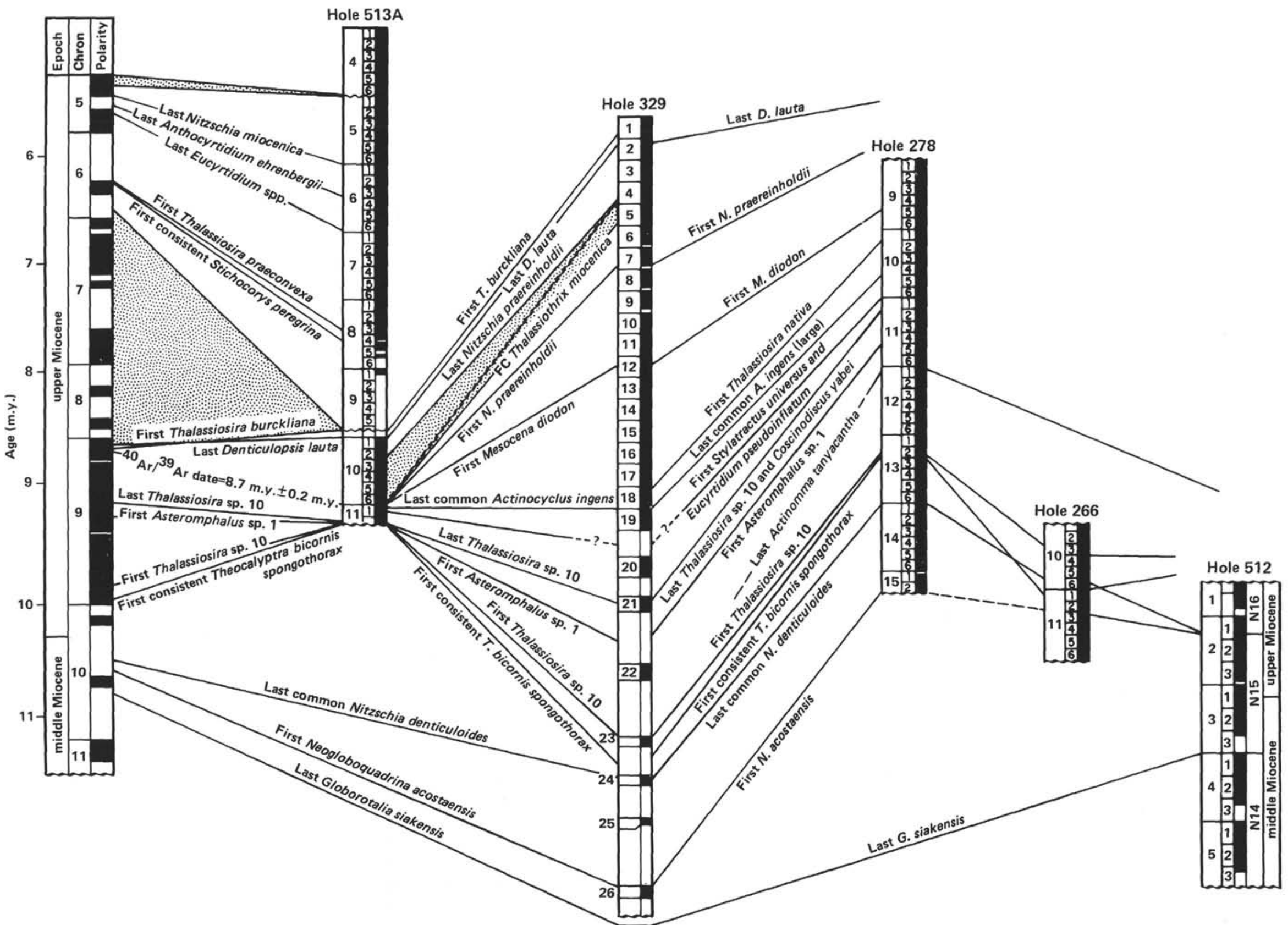


Table 3. Lowermost occurrence of IRD clasts in selected DSDP holes.

\begin{tabular}{|c|c|c|c|c|c|}
\hline Hole & Latitude & Longitude & $\begin{array}{l}\text { Sub-bottom } \\
\text { Depth (m) }\end{array}$ & $\begin{array}{l}\text { Section or Sample } \\
\quad \text { (level in } \mathrm{cm} \text { ) }\end{array}$ & $\begin{array}{c}\text { Age }(\mathrm{Ma}) \text { and } \\
\text { Paleomagnetic Correlation }\end{array}$ \\
\hline 514 & $46^{\circ} 02.77 \cdot \mathrm{s}$ & $26^{\circ} 51.29^{\prime} \mathrm{W}$ & 9.5 & $\begin{array}{l}514-3-2,99-102 \mathrm{~cm} \\
514-3-3,38-40 \mathrm{~cm}\end{array}$ & $\sim 0.78$; latest Matuyama Chron \\
\hline 513 & $47^{\circ} 34.99 \prime \mathrm{S}$ & $24^{\circ} 38.40^{\prime} \mathrm{W}$ & 153 & $513 \mathrm{~A}-10-1$ & $\sim 8.7$; late Chron 9 \\
\hline 328 & $49^{\circ} 48.67 \% \mathrm{~S}$ & $36^{\circ} 39.53^{\prime} \mathrm{W}$ & 13.5 & $328 \mathrm{~B}-1-4,150 \mathrm{~cm}$ & - 4.7-4.6; early Gilbert Chron \\
\hline 329 & $50^{\circ} 39.31 \cdot \mathrm{s}$ & $46^{\circ} 05.73^{\prime} \mathrm{W}$ & 4.5 & $329-1-3,150 \mathrm{~cm}$ & -2.64-2.49?; latest Gauss Chron? \\
\hline 266 & $56^{\circ} 24.13^{\prime} \mathrm{S}$ & $110^{\circ} 06.70^{\prime} \mathrm{E}$ & - & No IRD clasts present & \\
\hline 278 & $56^{\circ} 33.42^{\prime} \mathrm{S}$ & $160^{\circ} 04.29^{\prime} \mathrm{E}$ & 164.3 & $278-8.5,30 \mathrm{~cm}$ & late Pliocene? \\
\hline 267 & $59^{\circ} 15.74^{\prime} \mathrm{S}$ & $104^{\circ} 29.30^{\prime} \mathrm{E}$ & 11.63 & $267 \mathrm{~A}-1-6,13 \mathrm{~cm}$ & - 1.89-1.58; middle Matuyama Chron \\
\hline 322 & $60^{\circ} 01.45^{\prime} \mathrm{S}$ & $79^{\circ} 25.49^{\prime} \mathrm{W}$ & 79 & $322-1-2,100 \mathrm{~cm}$ & $\begin{array}{l}\text {-3.1-2.64; middle to late Gauss } \\
\text { Chron }\end{array}$ \\
\hline 269 & $61^{\circ} 40.57^{\prime} \mathrm{S}$ & $140^{\circ} 04.21^{\prime} \mathrm{E}$ & 46 & $269-2-1$ & $\begin{array}{l}\sim 3.1-2.64 ; \text { middle to late Gauss } \\
\text { Chron }\end{array}$ \\
\hline 323 & $63^{\circ} 40.84$ & $97^{\circ} 59.69^{\prime} \mathrm{V}$ & 370 & 323. & early Middle Miocene \\
\hline 268 & $63^{\circ} 56.99^{\prime} \mathrm{S}$ & $105^{\circ} 09.34^{\prime} \mathrm{E}$ & 145.7 & $268-7-2$ & $\begin{array}{l}\sim 8.7 \text { to } 8.5-4.48 ; \text { Chron 9-Gilbert } \\
\text { Chron }\end{array}$ \\
\hline 325 & $65^{\circ} 0$ & $73^{\circ} 4$ & 51 & 32 & early Miocene \\
\hline 274 & $68^{\circ} 59.81^{\prime} \mathrm{S}$ & $173^{\circ} 25.64^{\prime} \mathrm{E}$ & 113.05 & $274-12-6,105 \mathrm{~cm}$ & late Miocene; Chron 9 or 10 \\
\hline
\end{tabular}

to late Miocene sequences of most drill sites north of $58^{\circ} \mathrm{S}$ latitude were reexamined and correlated to the paleomagnetic time scale (Fig. 11) utilizing the diatom and radiolarian zonal schemes of Ciesielski (this volume) and Weaver (this volume). The stratigraphy of drill cores south of $58^{\circ} \mathrm{S}$ latitude was determined by utilizing the existing stratigraphic information published in the Initial Reports, with adjustments made through the use of the siliceous biostratigraphic studies of Weaver and Gombos (1981), Ciesielski (this volume), and Weaver (this volume).

Today the Polar Front coincides with a sediment facies boundary separating a southern biosiliceous facies south of the PFZ from a carbonate facies that exists north of the PFZ, in regions above the carbonate compensation depth. Thus, today the predominantly biosiliceous province corresponds to the extent of the Antarctic Surface Water Mass. A close association between the Cenozoic distribution of this facies and IRD suggests that its past distribution closely approximated the position of surface waters with similar temperatures (Tucholke et al., 1976).

The distribution of the Oligocene-early Miocene biosiliceous facies shown in Figure 10 is similar to its extent as previously shown by Tucholke et al. (1976). Our correlation of lower-latitude sites to magnetostratigraphy (Figure 11) does, however, allow a clearer analysis of the late middle Miocene to late Miocene development of the biosiliceous facies.

During portions of Chrons 11-9, deposition of mixed siliceous-calcareous oozes occurred at both deep-water Site 278 and intermediate-depth Site 512. Chronozone 10 sediment at Site 266 is predominantly siliceous, whereas at Site 329 Chronozone 10 and 9 sediments are predominantly calcareous with some zones of highly siliceous sediment. These relationships indicate that during most of late Chron 11 through most of Chron 9 the facies boundary between predominantly calcareous and siliceous facies was much more diffuse than today. Instead, a wide zone of mixed calcareous-siliceous sediment existed over a wide range of depth (3675-1519 m) and latitude $\left(56^{\circ} 34^{\prime} \mathrm{S}-50^{\circ} 39^{\prime} \mathrm{S}\right)$. Predominantly siliceous sediment apparently was restricted to south of the vicinity of Site $266\left(\sim 56-57^{\circ} \mathrm{S}\right.$ latitude). This suggests an indistinct Polar Front throughout the late middle Miocene and early late Miocene. Until late Chron 9, the lower latitudes of the Southern Ocean remained an important center of carbonate deposition.

Three sites $(278,329$, and 513$)$ reveal evidence of a northward migration of the predominantly biosiliceous facies during middle to late Chron 9. Mid-Chronozone 9 sediments of Site 278 become reduced in carbonate in Core 9, with a total loss of carbonate occurring in Section 278-9-2. Carbonate abundance also decreases in the upper Chronozone 9 sediments of Site 329 and disappears altogether above Section 329-1-4. Uppermost Chronozone 9 sediments of Site 513 are entirely biosiliceous, as are all Chronozone 6 and 5 sediments of the same hole.

The lithology of upper middle Miocene-upper Miocene sediments of Southern Ocean sites suggests that the Polar Front and the associated siliceous facies moved close to its present position over the Falkland Plateau during late Chron 9. For the first time this northward migration of the Polar Front brought truly antarctic waters over the Falkland Plateau; the first deposition of ice-rafted material quickly followed, at $\sim 8.7 \mathrm{Ma}$.

The distribution of IRD in the Southern Ocean offers important insight into glacial conditions in Antarctica. This is particularly true in the lower latitudes of the Southern Ocean, where most or all detritus is probably rafted upon large tabular bergs, which are the only type capable of travelling well beyond the limits of very cold surface water. Since these tabular bergs are principally produced by the ice shelves of West Antarctica, the first ice-rafting as far north as the Falkland Plateau signifies the presence of floating and at least partially grounded ice shelves in the West Antarctic region.

Ciesielski et al. (1982) interpret the initial occurrence of IRD in the lower-latitude regions of the Southern Ocean to represent the time when the West Antarctic ice sheet first became established. This inference is valid given the premise that the establishment of the West Antarctic ice sheet requires that it be buttressed by floating ice shelves, which are the major source of the tabular bergs carrying IRD to these latitudes (see Ciesielski et al., 1982, for a thorough discussion). On the basis of their review of the distribution of IRD and a wide vari- 
ety of other evidence, Ciesielski et al. (1982) conclude that the West Antarctic ice sheet first became established during late Chron 9 to Chron 7.

The temporal and geographic distribution of ice-rafted clasts and sand-sized IRD in Southern Ocean DSDP drill sites is shown in Figure 10 and Table 3. Clast and sand-sized IRD is rare in all late Miocene drill cores north of $62^{\circ} \mathrm{S}$ latitude, occurring only at Site 278 (Ciesielski et al., 1982) and Site 513. The presence of a $\sim 8.7$ m.y. old clast at Site 513 is the oldest evidence of icerafting to the northern Antarctic region. The only other occurrence of IRD in the late Miocene Site 513 is a zone of minor sand-sized IRD accumulation deposited between $\sim 5.57$ and $5.35 \mathrm{Ma}$. In all drill cores the rate of accumulation of sand-sized IRD and ice-rafted clasts is much greater during the Quaternary than during the Miocene.

The stratigraphic distribution of IRD and biogenic sediment facies suggest that:

1) Extensive ice shelves or ice tongues were not present along the Antarctic margin prior to Chron 9.

2) In the absence of ice shelves, no grounded ice sheet could have existed in West Antarctica.

3) Prior to this time, West Antarctica was instead occupied by an archipelago and the West Antarctic Sea.

4) Most IRD was deposited close to the continent by small bergs originating principally from tidewater glaciers and small fringing ice shelves.

5) Extensive ice shelves probably formed in the West Antarctic Sea by the early late Miocene, eventually coalescing and thickening to form the grounded West Antarctic ice sheet during Chron 9.

6) Once the West Antarctic ice sheet or shelf formed, cold antarctic surface waters expanded northward.

7) Ice-rafted detritus was then deposited in the lower latitudes of the Southern Ocean by large bergs from the newly formed ice shelves.

These conclusions are in close agreement with those of Ciesielski et al. (1982), who proposed a similar sequence of events for the late Miocene. The improved stratigraphic resolution provided by Leg 71 biostratigraphic studies now allows the conclusion that the West Antarctic ice sheet probably first became established during Chron 9.

The scarcity of late Miocene-early Pliocene IRD at lower latitudes suggests the inherently unstable West Antarctic ice sheet may have undergone repeated and lengthy episodes of ungrounding or even total destruction during its early history, after its initial Chron 9 formation. In our opinion, major late Miocene erosional events may have been caused during ungrounding episodes when the West Antarctic ice sheet thinned to form a vast, floating ice shelf. Such a shelf may have produced a larger volume of AABW, extensively eroding or inhibiting deposition of Southern Ocean sediments. Deposition of late Miocene IRD in the lower latitudes would probably be greater during times of ice-shelf grounding and West Antarctic ice-sheet formation. Thus, the major increase in the frequency of IRD accumulation and IRD accumulation rates that occurred at Leg 71 sites $\sim 4.35$ Ma may signal an increase in stability of the West Antarctic ice sheet.
If the West Antarctic ice sheet and its fringing ice shelves first formed during Chron 9, there should have been global changes in deep and bottom water circulation. Such evidence was found by Lohmann and Carlson (1981) in their analysis of the variability in the composition and distribution of late Miocene Pacific calcareous nannoplankton. They found the strongest contrast between the tropical and south temperate Pacific assemblages between 10 and $8 \mathrm{Ma}$ (Chron 9-late Chron 8). The strong latitudinal biogeographic differentiation of calcareous nannoplankton at this time was attributed to a more zonal surface circulation, which implies an associated decrease in latitudinal heat transport at the surface and an increase in heat transport at depth. They suggest that the source of the increased subsurface circulation that they propose is the deep and bottom waters of the Southern Ocean. This proposed increase in the production of Southern Ocean deep and bottom water at $10 \mathrm{Ma}$ is supported by a shallowing of calcite dissolution northward in the Pacific, indicating a southerly source of young deep water (Lohmann and Carlson, 1981).

At Site 289 , on the Ontong-Java Plateau, the benthic foraminiferal assemblage assumes modern-day characteristics by approximately $9 \mathrm{Ma}$ (Woodruff and Douglas, 1981). In addition, the Miocene benthic foraminifers of 22 Pacific sites exhibit faunal assemblages similar to those of the Quaternary by $8 \mathrm{Ma}$ (Woodruff and Douglas, in press).

In a detailed study of the Miocene stable isotope record of Site 289, Woodruff et al. (1981) found the highest Miocene $\delta^{18} \mathrm{O}$ values of benthic foraminifers between $\sim 9.5$ and $8.0 \mathrm{Ma}$. This suggests that this period exhibited the coldest Miocene bottom temperatures and/or the largest Miocene ice volume. A synthesis of the Miocene benthic foraminiferal isotopic records of 22 Atlantic, Pacific, and Indian Ocean DSDP sites reveals that highest $\delta^{18} \mathrm{O}$ values occurred between 8.5 and $7.5 \mathrm{Ma}$ (Savin et al., 1981).

This increase in the ${ }^{18} \mathrm{O}$ composition of global deep and bottom waters represents in part an increase in ice volume. Shackleton and Kennett (1975), in a study of the oxygen isotopic composition of benthic foraminifers at DSDP Site 284, concluded that the Antarctic ice sheet attained a late Miocene size $50 \%$ greater than at present. More recently Woodruff et al. (1981) have argued that the maximum late Miocene ice volume ( $\sim 9 \mathrm{Ma})$ appears similar to today's. Mercer and Sutter (1982), after reviewing the global record of late Miocene glaciation, icerafting, climatic cooling, and marine regression, concluded that "if global ice volume at the end of the Miocene was markedly greater than it is today, and the extra ice was not in Antarctica, it must have been in the Northern Hemisphere, probably within the area that was ice-covered by Pleistocene ice sheets." They estimate that ice volume was about one third to one half that of the late Pleistocene, in accordance with their estimated magnitude of marine regression (40-70 m).

We have suggested here that the West Antarctic ice sheet probably formed during Chron 9 , prior to the 8.7 $\mathrm{Ma}$ advent of ice-rafting to the Southwest Atlantic. Some of the Chron 9-Chron $8 \delta^{18} \mathrm{O}$ increase may be ac- 
counted for by the formation of the West Antarctic ice sheet; however, as Ciesielski et al. (1982) point out, the influence of West Antarctic ice on the oxygen isotopic composition of seawater is only $2-3 \%$ of the Tertiary change in the oxygen isotopic composition caused by ice storage. Although the late Miocene variability in benthic oxygen isotopes is quite low in deep ocean sites (Moore et al., 1981), some of this variation must be accounted for by increased East Antarctic ice accumulation and possibly some Northern Hemisphere ice accumulation. As to the volume of late Miocene Antarctic ice, the paucity of late Miocene IRD in the Southern Ocean is strong evidence against an Antarctic ice sheet as much as $50 \%$ greater than its present volume. If the West Antarctic ice sheet had exhibited any long-term late Miocene stability, icebergs from its fringing ice shelves should have rafted greater quantities of IRD to the lower latitudes of the Southern Ocean.

In the vicinity of Site 513 a latest Miocene reduction in AABW velocity occurred during earliest Chron 6 ( $\sim 6.5 \mathrm{Ma})$; this allowed continuous deposition until latest Chron $5(\sim 5.35 \mathrm{Ma})$. These sediments contain the oldest sand-sized IRD at Site $513(\sim 5.57-5.35 \mathrm{Ma})$, supporting the presence of the West Antarctic ice sheet during at least a portion of the Chron 6-Chron 5 interval. It is noteworthy the Chron 6-Chron 5 period of reduced AABW corresponds precisely with the Messinian (6.6-5.2 Ma) isolation and dessication of the Mediterranean Sea, which removed $6 \%$ of the ocean's dissolved salt. Lohmann and Carlson (1981) suggested that this Messinian reduction in global ocean salinity would have slowed, or even briefly stopped, the production of deep waters. This explanation, they believe, would account for the Messinian-age calcareous nannofossil characteristics in the Pacific that indicate reduced latitudinal climatic contrast and imply reduced zonality of surface circulation and associated latitudinal heat transport by deep water.

\section{CONCLUSIONS}

1. High-velocity $\mathrm{AABW}$ created a regional upper lower to lower upper Miocene disconformity between the Islas Orcadas Rise and the Mid-Atlantic Ridge and in the southeast Argentine Basin. A portion or all of the erosional episode which produced this disconformity occurred in the late Miocene and terminated $\sim 9.0$ to 9.5 Ma.

2. An $\sim 8.7$ m.y. old ice-rafted clast found in Hole $513 \mathrm{~A}$ is the oldest evidence of ice-rafting to the lower latitudes of the Southern Ocean. The presence of this clast suggests at least temporary presence of large Antarctic ice shelves or sea-level ice tongues before this time.

3. Sedimentation resumed at Site 513 during late Chron $9(\sim 9.5 \mathrm{Ma})$ but was again interrupted by nondeposition or erosion that created a Chron 8 and Chron 7 disconformity.

4. Sedimentation once again resumed at Site 513 during Chrons 6 and 5, but was interrupted for a brief time in latest Chron 5. The first minor influx of sand- size IRD occurred at $\sim 5.57-5.35 \mathrm{Ma}$, immediately preceding the late Chron 5 hiatus.

5. Late Miocene and late middle Miocene sequences of a number of Southern Ocean DSDP sites, re-examined in a attempt to revise the stratigraphy according to recent siliceous microfossil stratigraphic studies of Weaver and Gombos (1981), Ciesielski (this volume), and Weaver (this volume), suggest that:

a) Clast and sand-sized IRD is rare in all late Miocene drill cores north of $\sim 62^{\circ} \mathrm{S}$ latitude, occurring only at Sites 278 and 513. Minor ice-rafting to the lower latitudes began by $8.7 \mathrm{Ma}$.

b) In all cores north of $\sim 65^{\circ} \mathrm{S}$ latitude, the rates of late Miocene IRD accumulation were much less than during the Pliocene-Pleistocene.

c) The predominantly biosiliceous province of sedimentation did not move into the lower latitudes of the Southern Ocean until the late Miocene $(\sim$ latest Chron 9).

d) Late Miocene erosion and/or nondeposition has removed Chronozones $8-5$ sediment $(\sim 8.5-5.2 \mathrm{Ma})$ from all drill core sites except Site 513, where Chronozone 6 and 5 sediments were deposited.

6. These characteristics of late Miocene sedimentation suggest to us that

a) The Polar Front first migrated to the northern latitudes of the Southern Ocean during the late Miocene.

b) Extensive ice shelves or ice tongues were not present along the Antarctic margin until late Chron $9(\sim 9.0$ Ma).

c) With the absence of ice shelves, no grounded ice sheet is likely to have existed in West Antarctica prior to Chron 9. Present-day West Antarctica was then occupied by an archipelago and the West Antarctic Sea.

d) Extensive ice shelves probably formed in the West Antarctic region during Chron 9, eventually coalescing and thickening to form the grounded West Antarctic ice sheet.

e) The West Antarctic ice sheet was probably highly unstable during the latest Miocene and most likely was rarely grounded, thus possibly accounting for the scarcity of late Miocene IRD.

f) The paucity of latest Miocene sediment (Chrons $8-5$ ) in the Southern Ocean may be the result of greatly increased $\mathrm{AABW}$ formation in the West Antarctic region during times when the West Antarctic ice sheet ungrounded.

7. Southwest Atlantic AABW velocity decreased in early Chron 6 . This allowed apparently continual deposition until late Chron 5, when deposition was once again was interrupted briefly.

8. The late Gilbert Chron heralds a major and permanent change in the pattern of ice-rafting into the Southwest Atlantic. After 4.35 Ma major episodes of IRD accumulation are more frequent and the accumulation rate of IRD increases. This permanent change in frequency of IRD deposition is, we suggest, a response to the increased stability of the West Antarctic ice sheet.

9. The position of the Polar Front relative to Site 514 during the last 4.07 m.y. was reconstructed using ra- 
diolarian faunas of Hole 514. Eight migrations of the Polar Front to the north of Site 514 were noted, at approximately $4.0-3.9,3.1,2.7-2.6,2.5,2.4-1.9,1.6$, and 0.7-0.4 Ma.

10. At $\sim 2.7-2.6 \mathrm{Ma}$, a major change occurred in the frequency of Polar Front migrations over Site 514. This, it is suggested, is partially in response to oceanic change induced by fluctuations in Northern Hemisphere glacial conditions.

11. Middle Pliocene sediment, 3.85-3.10 m.y. old, is absent at all four sites, suggesting an increase in the velocity of both AABW and Circumpolar Deep Water in these areas during the latest Gilbert through early Gauss chrons.

12. A comparison of IRD accumulation rates at Sites 513 and 514 suggests that the mean position of the Polar Front was closer to the more northerly Site 514 during much of the Matuyama Chron, but further to the south, closer to Site 513, throughout much of the Brunhes Chron.

\section{ACKNOWLEDGMENTS}

Dr. Douglas Williams and Dr. Peter N. Webb are thanked for a critical review of the manuscript. Ms. Barbara Daniel drafted the text figures. Partial financial support for this research was provided by NSF Grant DPP-811347 to M. T. Ledbetter and P. F. Ciesielski.

\section{REFERENCES}

Bandy, O. L., Casey, R. E., and Wright, R. C., 1971. Late Neogene planktonic zonation, magnetic reversals, and radiometric dates, antarctic to the tropics. In J. L. Reid (Ed.), Antarctic Oceanography 1. Am. Geophys. Un., Antarct. Res. Ser. 15:1-26.

Berggren, W. A., 1972. Late Pliocene-Pleistocene glaciation. In Laughton, A. S., Berggren, W. A., et al., Init. Repts. DSDP, 12: Washington (U.S. Govt. Printing Office), 953-963.

Ciesielski, P. F., 1978. The Maurice Ewing Bank of the Malvinas (Falkland) Plateau: Depositional and erosional history and its paleoenvironmental implications [Ph.D. dissert.]. Florida State University, Tallahassee.

Ciesielski, P. F., Ledbetter, M. T., and Ellwood, B. B., 1982. The development of Antarctic glaciation and the Neogene paleoenvironment of the Maurice Ewing Bank. Mar. Geol., 46:1-51.

Gordon, A. L., Georgi, D. T., and Taylor, H. W., 1977. Antarctic Polar Front Zone in the Western Scotia Sea, Summer 1975. Phys. Oceanogr., 7:309-328.

Hays, J. D., 1965. Radiolaria and late Tertiary and Quaternary history of Antarctic seas. In Hano, G. A. (Ed.), Biology of the Antarctic Seas, II. Am. Geophys. Un., Antarct. Res. Ser. 5:125-184.

Hays, J. D., and Opdyke, N. D., 1967. Antarctic radiolaria, magnetic reversals, and climate changes. Science, 158:1001-1011.

Keany, J., 1978. Paleoclimatic trends in early and middle Pliocene deep-sea sediments of the Antarctic. Mar. Micropaleontol., 3: 35-49.

Kennett, J. P., 1978. The development of planktonic biogeography in the Southern Ocean during the Cenozoic. Mar. Micropaleontol., 3:301-345. Hall).

Ledbetter, M. T., and Ciesielski, P. F., 1982. Bottom current erosion in the South Atlantic sector of the Southern Ocean. Mar. Geol., 46:329-341.

Lohmann, G. P., and Carlson, T. J., 1981. Oceanographic significance of Pacific late Miocene calcareous nannoplankton. Mar. Micropaleontol., 6:553-579.

Lozano, J. A., and Hays, J. D., 1976. Relationship of radiolarian assemblages to sediment types and physical oceanography in the At- lantic and western Indian Ocean sectors of the Antarctic Ocean. In Cline, R. M., and Hays, J. D. (Eds.), Investigation of Late Quaternary Paleoceanography and Paleoclimatology. Geol. Soc. Am. Mem., 145:303-336.

Mercer, J. H., 1976. Glacial history of southernmost South America. Quat. Res., 6:125-166.

Mercer, J. H., Fleck, R. T., Mankinen, E. A., and Sander, W., 1975. Southern Patagonia: Glacial events between 4 MY and 1 MY. In Suggate, R. P., and Cresswell, M. M. (Eds.), Quaternary Studies. Soc. N. Z. Bull., 13:223-230.

Mercer, J. H., and Sutter, J. F., 1982. Late Miocene-earliest Pliocene glaciation in Southern Argentina: Implications for a global icesheet history. Paleogeogr. Paleoclimatol. Paleoecol., 38:185-206.

Moore, T. C., Jr., Pisias, N. G., and Keigwin, L. D., 1981. Ocean basin and depth variability of isotopes in Cenozoic benthic foraminifera. Mar. Micropaleontol., 6:465-481.

Nigrini, C., 1967. Radiolaria in Pelagic Sediments from the Indian and Atlantic Oceans. SIO Bull. 11.

Nigrini, C., and Moore, T. C., 1979. A Guide to Modern Radiolaria. Cushman Found. Foraminiferal Res. Spec. Publ. 16.

Osborn, N. I., Ciesielski, P. F., and Ledbetter, M. T., in press. Disconformities and paleoceanography in the Southwest Indian Ocean during the last 5.4 million years. Geol. Soc. Am. Bull.

Payne, R. D., 1977. Radiolaria in Brunhes sediments of the Southeast Indian Ocean south of Australia [Ph.D. Dissert.]. University of South Carolina, Columbia.

Petrushevskaya, M. G., 1968. Radiolarians of orders Spumellaria and Nassellaria of the Antarctic region. In Andriyashev, A. P., and Ushakov, P. V. (Eds.), Biological Reports of the Soviet Antarctic Expedition (1955-1958): Washington, D. C. (Israel Program for Scientific Translations/N.S.F.), 3:2-186.

Savin, S. M., Douglas, R. G., Keller, G., Killingley, J. S., Shaughnessy, L., Sommer, M. A., Vicent, E., Woodruff, F., 1981. Miocene benthic foraminiferal isotope records: a synthesis. Mar. Micropaleontol., 6:423-450.

Shackleton, N. J., and Kennett, J. P., 1975. Paleotemperature history of the Cenozoic and initiation of Antarctic glaciation: oxygen and carbon isotope analysis in DSDP Sites 277,279 , and 281 . In Kennett, J. P., Houtz, R. E., et al., Init. Repts. DSDP, 29: Washington (U.S. Govt. Printing Office), 743-755.

Shackleton, N. J., and Opdyke, N. D., 1977. Oxygen isotope and paleomagnetic evidence for early Northern Hemisphere glaciation. Nature, 270:216-219.

Stainforth, R. M., et al., 1975. Cenozoic Planktonic Foraminiferal Zonation and Characteristics of Index Forms. Univ. Kansas Paleontol. Contrib. 62 .

Tucholke, B. E., Hollister, C. D., Weaver, F. M., and Vennum, W. R., 1976. Continental rise and abyssal plain sedimentation in the southeast Pacific basin-Leg 35 Deep Sea Drilling Project. In Hollister, C. D., Craddock, C., et al., Init. Repts. DSDP, 35: Washington (U.S. Govt. Printing Office), 359-400.

Weaver, F. M., 1973. Pliocene paleoclimatic and paleoglacial history of East Antarctica recorded in deep-sea piston cores. Florida State Univ. Sedimentol. Res. Lab. Contrib., 36:142.

1976. Late Miocene and Pliocene radiolarian paleobiogeography and biostratigraphy of the Southern Ocean [Ph.D. dissert.]. Florida State University, Tallahassee.

Weaver, F. M., and Gombos, A. M., 1981. Southern high latitude diatom biostratigraphy. In Warme, T. E., Douglas, R. C., and Winterer, E. L. (Eds.). The Deep Sea Drilling Project: A Decade of Progress. Soc. Econ. Paleont. Mineral. Spec. Publ. 32:445-470.

Weaver, F. M., and McCollum, D. W., 1974. Sedimentary hiatus in the South Indian Basin. Antarct. J. U.S., 9:250-251.

Woodruff, F., and Douglas, R. G., 1981. Response of deep-sea benthic foraminifera to Miocene paleoclimatic events, DSDP Site 289. Mar. Micropaleontol., 6:617-632.

in press. The impact of Miocene climatic fluctuations on deep sea benthic foraminifera in the Pacific Ocean. Nature.

Woodruff, F., Savin, S. M., and Douglas, R. G., 1981. Miocene stable isotope record: A detailed deep Pacific Ocean study and its paleoclimatic implications. Science, 212:665-668. 